\title{
Mitochondria as a Cellular Hub in Infection and Inflammation
}

\author{
Pauline Andrieux ${ }^{1}$, Christophe Chevillard ${ }^{1, *}$, Edecio Cunha-Neto ${ }^{2,3}$, and João Paulo Silva Nunes $1,2,3, *$ \\ 1 Inserm, INSERM, UMR_1090, Aix Marseille Université, TAGC Theories and Approaches of Genomic \\ Complexity, Institut MarMaRa, 13288 Marseille, France; Pauline.Andrieux@outlook.com \\ 2 Laboratory of Immunology, Heart Institute (InCor), Division of Clinical Immunology and Allergy, School of \\ Medicine, University of São Paulo, São Paulo 05403-000, Brazil; edecunha@gmail.com \\ 3 Institute for Investigation in Immunology (iii), INCT, São Paulo 05403-000, Brazil \\ * Correspondence: christophe.chevillard@univ-amu.fr (C.C.); jpaulo.nunes@live.com (J.P.S.N.); \\ Tel.: +33-491828736 (C.C.); +55-31-99496-7165 (J.P.S.N.); Fax: +33-491828701 (C.C.)
}

Citation: Andrieux, P.; Chevillard, C.; Cunha-Neto, E.; Nunes, J.P.S. Mitochondria as a Cellular Hub in Infection and Inflammation. Int. J. Mol. Sci. 2021, 22, 11338. https:// doi.org/10.3390/ijms222111338

Academic Editor: Masashi Tanaka

Received: 8 October 2021

Accepted: 13 October 2021

Published: 20 October 2021

Publisher's Note: MDPI stays neutral with regard to jurisdictional claims in published maps and institutional affiliations.

Copyright: (c) 2021 by the authors. Licensee MDPI, Basel, Switzerland. This article is an open access article distributed under the terms and conditions of the Creative Commons Attribution (CC BY) license (https:// creativecommons.org/licenses/by/ $4.0 /)$.

\begin{abstract}
Mitochondria are the energy center of the cell. They are found in the cell cytoplasm as dynamic networks where they adapt energy production based on the cell's needs. They are also at the center of the proinflammatory response and have essential roles in the response against pathogenic infections. Mitochondria are a major site for production of Reactive Oxygen Species (ROS; or free radicals), which are essential to fight infection. However, excessive and uncontrolled production can become deleterious to the cell, leading to mitochondrial and tissue damage. Pathogens exploit the role of mitochondria during infection by affecting the oxidative phosphorylation mechanism (OXPHOS), mitochondrial network and disrupting the communication between the nucleus and the mitochondria. The role of mitochondria in these biological processes makes these organelle good targets for the development of therapeutic strategies. In this review, we presented a summary of the endosymbiotic origin of mitochondria and their involvement in the pathogen response, as well as the potential promising mitochondrial targets for the fight against infectious diseases and chronic inflammatory diseases.
\end{abstract}

Keywords: mitochondria; inflammation; infection; mitochondria dysfunction; mitochondrial bioenergetics; infection disease; inflammatory disease

\section{Introduction}

Mitochondria are membrane-bound organelles, essential to produce energy in the form of ATP, because the phosphate is a high-energy bond and provides energy for other reactions within the cell. In addition to producing energy, mitochondria store calcium for cell signaling activities, generate heat and mediate cell growth and death. The number of mitochondria per cell varies widely according to the local energy demand. However, restricting mitochondria merely as an energy power organelle is to miss the big picture. The mitochondria's oxidative phosphorylation (OXPHOS) is a major site for the production of reactive oxygen species (ROS; or free radicals) due to the high propensity for aberrant release of free electrons. While several different antioxidant proteins within the mitochondria scavenge and neutralize these molecules, excessive ROS production may inflict damage to mtDNA. Mitochondrial dynamics and energetics play a central role in proinflammatory signaling, thus are essential organelles for the control of innate immunity and inflammatory response against infectious pathogens.

\section{An Evolutionary Cooperation between Mitochondria and Eukaryotic Cells}

The eukaryotic term includes all multicellular organisms (such as animals, fungi and plants) and unicellular organisms (e.g., protozoa) composed of eukaryotic cells. The eukaryotic cell is defined essentially by the existence of a structured nucleus and the presence of organelles in the cytoplasm such as mitochondria in contrast to prokaryotes. The mitochondria are the powerhouse of the cell, indeed, through the OXPHOS mechanism. 
The first descriptions of these organelles were performed in 1890 by Richard Altmann. He observed the existence of granula inside the cells stained with osmium and called them "bioblasts". He described them as "elementary organisms" with autonomy in terms of metabolism and genetics. The name mitochondria came only later, in 1898, when Carl Benda named it from the Greek "mitos" (thread) and "chondros" (granule). Similarities between mitochondria and prokaryotes can also be found in the composition of their membranes. Indeed, both the inner membrane of the mitochondria and prokaryotic membrane share a phospholipid essential to the organization of these membranes: cardiolipin [1]. Moreover, genetic information is stored in the form of circular DNA in prokaryotes and mitochondria [2].

These similarities raised some questions about the origin of the eukaryotic cell. Previously, it was considered that the eukaryotic cells descended from an ancestral lineage that gradually became more complex due to numerous mutations. However, in 1918, Paul Poitier talked about symbionts: "These organelles would be for me nothing other than symbiotic bacteria, what I call symbionts". Several years later, in 1967 the endosymbiotic theory was developed by Margulis "During the course of the evolution of mitosis, photosynthetic plastids (themselves derived from prokaryotes) were symbiotically acquired by some of these protozoans to form the eukaryotic algae and the green plants." [3]. In 1998, Martin and Müller proposed the "hydrogen hypothesis for the first eukaryote". This hypothesis suggested the mutualist symbiosis between an Archaean type host cell and an alphaproteobacteria. Indeed, the host cell would need to live on hydrogen in the medium and would produce methane in metabolic residues. Whereas the symbiont, alphaproteobacteria would be an optional aerobic organism that either carry out the fermentation that produces hydrogen as waste or breathe in the presence of oxygen [4]. Both the host and the symbiont benefit from this association.

After several studies to confirm the prokaryotic origin of the mitochondria, we could wonder when the evolution of the eukaryotic cell's endosymbiosis has occurred. Several theories on the occurrence of mitochondria could explain the formation of prokaryotic cells. The first model (mito-late) is referred to by the event that the mitochondria appeared when the cell had already acquired a certain complexity. A second model suggested that mitochondria appeared before the complexification of the cell, and it would be precisely the acquisition of this organelle which allowed the cell to: the mito-early model.

Regardless of whether the mitochondria arrived early or late, we can think that their appearance led to a number of changes within the host that allowed its evolution to the eukaryotic cells we know today. Indeed, the evolution of the endomembrane system is part of the great changes brought by the endosymbiosis of an archaea and an alphaproteobacteria. Some biologists believed that the mitochondria within the archaea exerted a pressure that allowed the establishment of the endomembrane system, in particular through the secretion of vesicles [5].

The mitochondria are composed of a circular genome of $16.6 \mathrm{~kb}$ [1]. Unlike nuclear DNA, the mtDNA is not associated with histone proteins and is present in one or more copies per organelle. This genome encodes 13 proteins required for the OXPHOS, the $12 \mathrm{~S}$ and $16 \mathrm{~S}$ rRNAs and 22 tRNAs [6]. Due to the conservation of the primary structure of the different rRNA subunits, it was possible to elaborate the first phylogenetic tree between mitochondria and proteobacteria [7-9], and which made it possible to identify alphaproteobacteria as close to the mitochondria [10]. When comparing this genome with the alphaproteobacteria genome, although homologous, a large part of the mitochondrial genome was lost from its ancestral alphaproteobacteria [11,12]. The loss of these genes could be explained by the elimination of genes that were not essential for the correct functioning of this microorganism in its new environment. If genes with the same usefulness are found in the nucleus, we might think that those found in the mitochondria were lost to avoid costly energy redundancy [11-14]. This could also be explained by a gene transfer from the mitochondrial genome to the nuclear genome [15-17]. Finally, some studies suggest a suppression of redundant and non-essential genes by random mutations [18]. 
In addition, mitochondria also played a role in the mechanism of programmed cell death, apoptosis. Apoptosis is an essential mechanism of homeostasis [19], apoptotic signals lead to permeabilization of the mitochondrial membrane and release of cytochrome C, which activates caspases. This activation leads to chromatin condensation, nuclear fragmentation and ultimately the cells are fragmented and eliminated by macrophages without the induction of inflammation. Kroemer was the first to propose that apoptosis evolved during the domestication of ancestral mitochondria with the ancestral host cells as a defense mechanism against the host cell [20]. A more recent study, interested in reconstructing the apoptotic machinery at the level of the ancestral mitochondria, has shown that the establishment of apoptosis is the result of a co-evolution between the ancestral mitochondria and the host. In the course of evolution, the ancestral mitochondria and the host have each set up weapons to eliminate the other. It is the co-evolution of these two organisms that has allowed creating the programmed cell death mechanism as we know today [21]. The ancestral mitochondria had indeed released toxins and proteases such as caspases and meta caspases against the host. The host has evolved to protect itself by releasing protease inhibitors. These defense mechanisms have continued until it stabilized and gave rise to the programmed cell death mechanism [21].

The OXPHOS system is also an indicator of co-evolution between the ancestral mitochondria and the host cell since we found a reduction of the ancestral mitochondrial genome through the host cell genome profile. Indeed, oxidative phosphorylation protein components, which is an essential mechanism of this organelle, is encoded both by mtDNA coding factors and by the nuclear genome [22]. Knowing that the mechanism of oxidative phosphorylation is a mechanism inherited from the ancestral mitochondria, this is proof that during the domestication of the mitochondria by the cell, gene exchanges were carried out to favor the survival of the two symbionts. Moreover, the co-evolution between the ancestral mitochondria and the host was done in a very specific way for each species. Indeed, cellular hybrids made between a human nucleus and chimpanzee or gorilla mitochondria show a $20 \%$ decrease in endogenous cellular respiration $[23,24]$. The respiratory chain allows the generation of energy for the cell. For many, the acquisition of this mechanism has been a pillar of the evolution of eukaryotic cells. By increasing energy production [25], the ancestral cell was able to extend its genome and to allow an increase in cellular complexity [26]. Indeed, this increased energy allowed the eukaryotic cell to set up several mechanisms such as the cell cycle, endomembrane traffic [26], the nucleus compartmentalization [27] and the ability to become multicellular.

\section{Mitochondria: General Concepts}

\subsection{Mitochondrial Respiratory Complexes}

The mitochondria are composed of two lipid bilayer membranes, the outer and the inner membrane, which are separated by the intermembrane space. The inner membrane is organized in the form of invaginations called ridges. Under the inner membrane is located the mitochondrial matrix, in which the mitochondrial DNA and ribosomes are found (Figure 1).

The mitochondrial respiratory chain corresponds to a protein complex association at the level of the mitochondrial inner membrane. This respiratory oxidative phosphorylation chain is a key biological process that allows the phosphorylation of ADP to ATP through ATP synthase thanks to the energy released by the oxidation of electron donors (NADH and FADH2) through the respiratory chain [28].

The two electron donors NADH and FADH2 come from the tricarboxylic acid cycle (TCA cycle). Acetyl-coenzyme A (Acetyl-CoA) is a metabolite derived from the degradation of glucose, fatty acids and amino acids and is the first intermediate metabolite of the TCA pathway, being later combined with oxaloacetate to generate citrate. Citrate is converted into isocitrate, which is converted by two oxidative decarboxylations in $\alpha$-ketoglutarate and succinyl-CoA. This reaction generates $\mathrm{CO}_{2}$ and two molecules of NADH. The NADH generated at this stage transfers electrons mainly to the complex I of the respiratory 
chain. After succinyl-CoA is converted into succinate, the oxidation of succinate generates fumarate and the electron donor FADH2, which will donor electrons to complex II. Later, the fumarate is converted into malate then in oxaloacetate and the cycle then restarts [29].

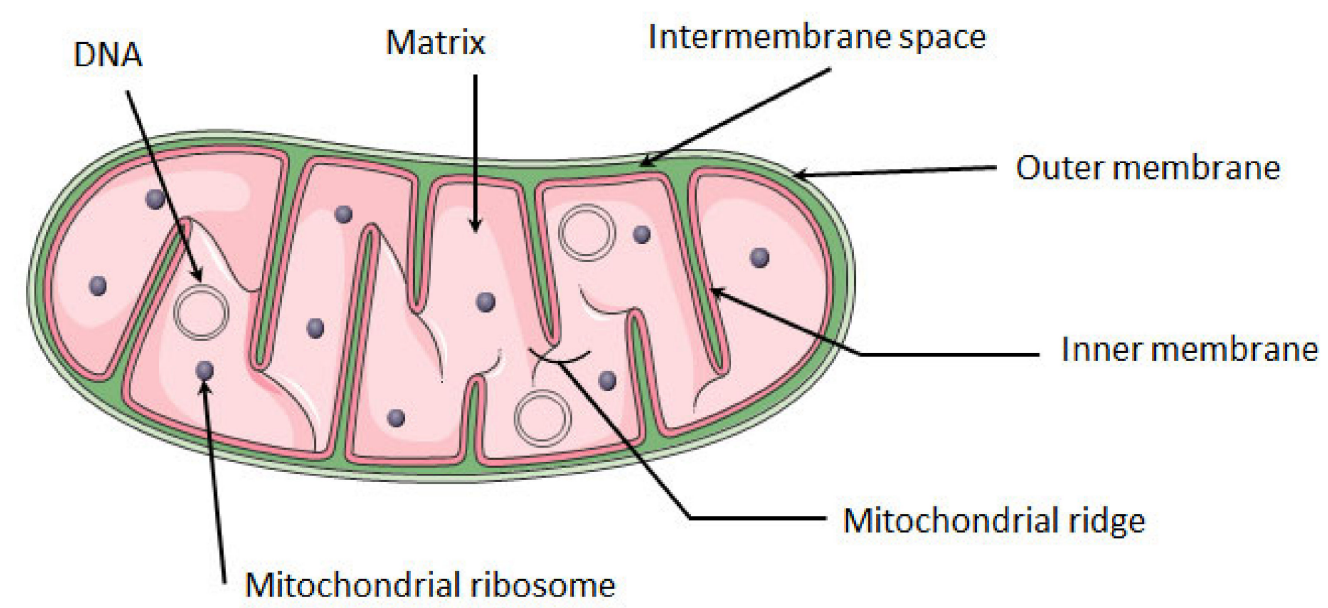

Figure 1. Structure of mitochondria. The mitochondrion is composed of a double membrane: the inner membrane and the outer membrane. Between these membranes is the intra-membrane space. The inner membrane forms invaginations called ridges where the OXPHOS complexes are located. The mitochondrial matrix contains several copies of mitochondrial circular DNA and ribosomes. Mitochondria image adapted from Smart. Available online: https://smart.servier.com (accessed on 10 August 2021).

The respiratory OXPHOS chain is composed of five complexes and two coenzymes. Complex I is a NADH: coenzyme Q oxidoreductase, composed of 46 subunits, 7 of these subunits are encoded by mtDNA and the others by nuclear DNA. The 14 central subunits execute the bioenergetic function of this complex. In addition to these central subunits the complex I may have accessory subunits, but these subunits are not implicated in bioenergetic function, their function is not well known, however it is possible that they could improve electron transport [30].

Complex I allows the oxidation of NADH by the quinone coenzyme Q10 (CoQ10), releasing two electrons to Complex III and pumping four protons $\left(\mathrm{H}^{+}\right)$from the mitochondrial matrix to the inter-membrane space.

Complex II is exclusively encoded by the nuclear DNA and has four subunits with a succinate: coenzyme $Q$ reductase mechanism of action. Its main role in the OXPHOS is to transfer the electrons from the succinate to fumarate oxidation to CoQ10. Since this redox reaction is of low energy, complex II does not contribute to the $\mathrm{H}^{+}$gradient in the mitochondria.

Complex III is a CoQ10-cytochrome $\mathrm{C}$ oxidoreductase composed of 10 subunits. The cytochrome $\mathrm{B}$, a central protein of this complex, is encoded by mtDNA and the other subunits are encoded by nuclear DNA. The passage of electrons from CoQ10 to cytochrome C pumps four $\mathrm{H}^{+}$to the intermembrane space.

Cytochrome $\mathrm{C}$ enables the transition of electrons between the complexes III and IV. The complex IV has a cytochrome $\mathrm{C}$ oxidase action which transports two protons in the opposite direction of the gradient and reduces $\mathrm{O}_{2}$ in a $\mathrm{H}_{2} \mathrm{O}$ molecule. This complex is composed of 20 subunits, 3 encoded by mtDNA. Finally, all the protons present in intermembrane spaces pass through the ATP synthase. The force of this proton gradient leads to the synthesis of ATP from ADP and inorganic phosphate (Figure 2) [28]. 

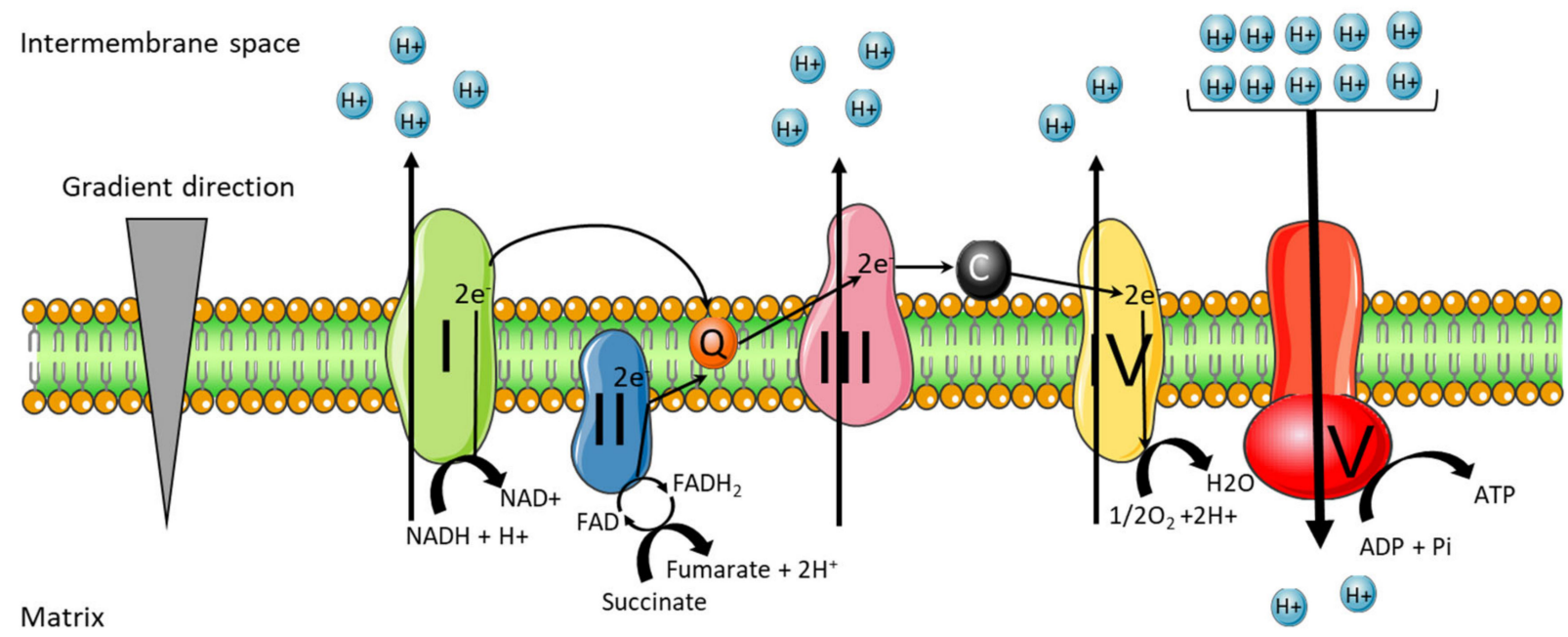

Matrix

Succinate

(H+) $\mathrm{H}+$

Figure 2. Mitochondrial respiratory chain complex. The mitochondrial respiratory chain is located at the inner membrane of the mitochondria. Composed of four complexes and two coenzymes, it allows the production of ATP through oxidative phosphorylation. Complex I (NADH: coenzyme Q oxidoreductase) and II (succinate dehydrogenase) will each transfer two electrons to the quinone coenzyme Q10 (CoQ10). The two electrons transferred from complex I come from the oxidation of $\mathrm{NADH}$, and those from complex II come from oxidation of succinate to fumarate. CoQ10 will allow the transfer of electrons to complex III (CoQ10-cytochrome C oxidoreductase). The complex III will then pass these electrons to the cytochrome $\mathrm{C}$, which makes the link with the complex IV (cytochrome C oxidase). The complex IV reduces $\mathrm{O}_{2}$ in a $\mathrm{H}_{2} \mathrm{O}$ molecule. Complexes I, III and IV are proton pumps, which allow the passage of protons from the matrix to the intermembrane space, in the opposite direction of the gradient. Complexes I and III allow the passage of four protons and complex IV of two protons. Once the intermembrane space is enriched with protons, the last complex of the chain, ATP synthase will allow the passage of protons in the direction of the gradient. This proton flow will allow the synthesis of ATP from ADP.

The ATP synthase is composed of 29 subunits, these subunits can be separated in two functionally regions: $\mathrm{F}_{0}$ and $\mathrm{F}_{1} . \mathrm{F}_{0}$ is in the intermembrane and $\mathrm{F}_{1}$ is on the mitochondrial matrix. Throughout all major respiratory chain complexes, the passage of electrons pumps protons outwards. This flow creates an electrochemical energy inside the mitochondria, called the proton motive force [31].

The mitochondrial complexes stably interact with each other in the supercomplexes as proposed by the "Solid-state model" [32]. Two different supercomplexes were isolated from bovine heart and yeast cells using a blue native polyacrylamide gel electrophoresis (BN-PAGE) technique: $\mathrm{I}_{1} \mathrm{III}_{2} \mathrm{IV}_{4}$ and $\mathrm{III}_{2} \mathrm{IV}_{4}$. The association of complexes I, III and IV is called "respirasome" (Figure 3) [33,34].

In order to study the direct passage of electrons between the complexes, the metabolic flux control coefficient was calculated [35] and an association between complexes I and III was observed, while complex IV seems to be randomly distributed. In addition, the authors did not identify a direct electron channel between complex II and complexes III and IV [36]. In mammals, super complexes are most often composed of complexes I, III and IV, in the form I $+\mathrm{III}_{2}+\mathrm{IV}_{1-4}$ and I $+\mathrm{III}_{2}$. It has been shown that there is an increase in these complexes in the human skeletal muscles during effort, which shows that these super complexes are encoded according to the energy demand [37].

Another argument in favor of solid-state models is that the stability of supercomplexes depends on the complexes that constitute them. Indeed, a mutation in the assembly site in complex III leads to a deficiency of complex III as well as supercomplex I + III and a reduction of the amount of complex I. [38]. Complex IV is also necessary for the assembly or stability of complex I [39].

The organization of the mitochondrial ridges also participate in the stability of the supercomplexes. The mitochondrial ridges owe their organization on one side to the mitochondrial 
contact site and cristae organizing system (MICOS), this complex is found at the base of the ridges [40-42]. The MIC10 subunit of the MICOS complex is particularly important in the formation of these ridges $[43,44]$. ATP synthase also plays an important role in the stabilization of these ridges, being organized in dimers at the top of the ridges $[45,46]$. The other respiratory complexes seem to be located at the level of the flat surfaces of the ridges $[47,48]$.

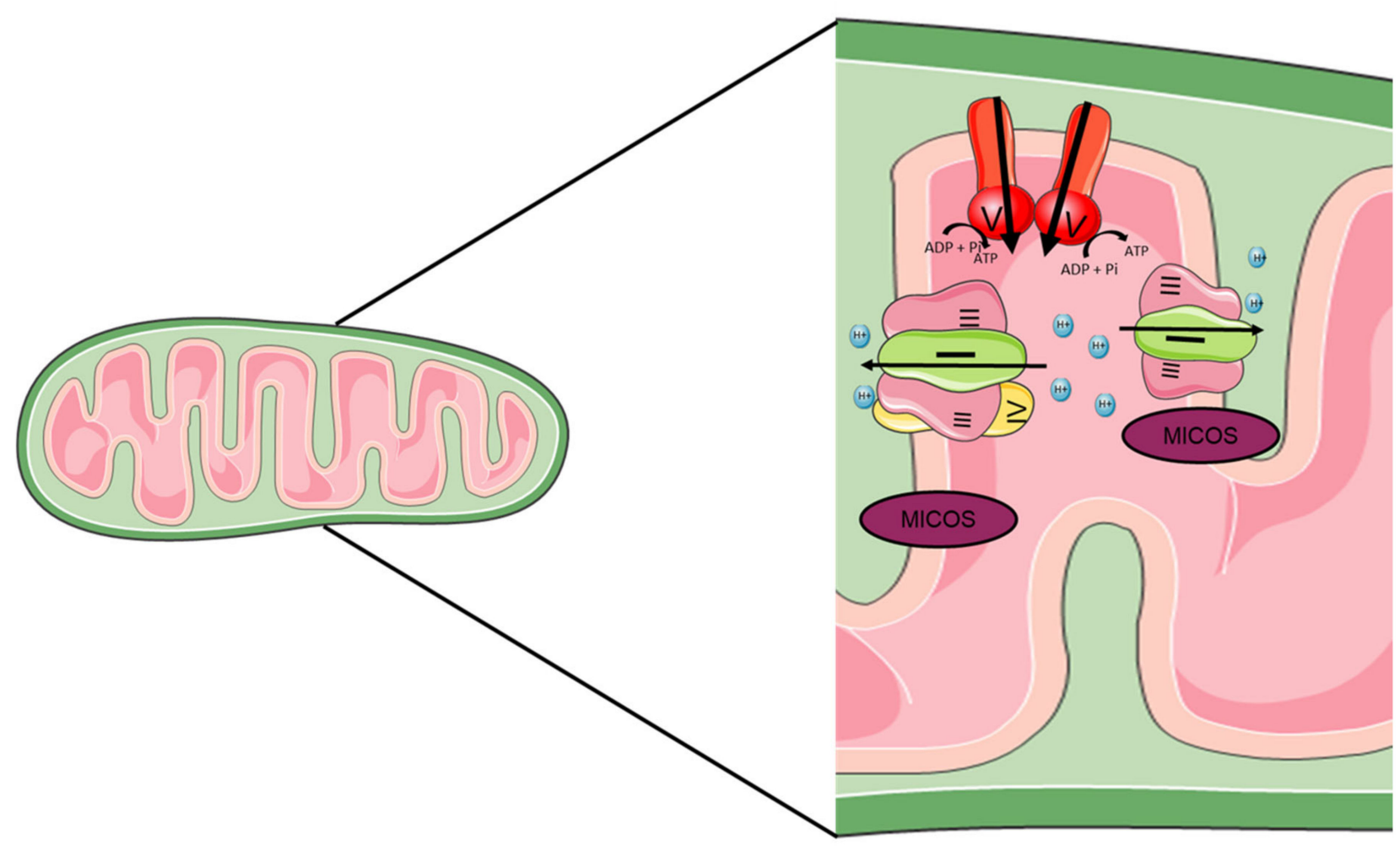

Figure 3. Structure of mitochondrial supercomplexes. The structure of the mitochondrial ridges is very important in the function of mitochondria and in particular in the stability of the super complex. Several proteins are involved in the stability of these ridges, the ATP synthase which will be at the top and the mitochondrial contact site and cristae organizing system (MICOS) which will be at the bottom. Between the two will be the super complexes. The two main super-complexes found in mammals I + III2 + IV1-4 and I + III2 are shown.

\subsection{Mitochondrial Dynamics}

Mitochondrial fission and fusion mechanisms maintain functional mitochondria when the cells experience metabolic or environmental stresses (Figure 4).

Fusion helps mitigate stress by mixing the contents of partially damaged with fully functional mitochondria as a form of complementation. Fission is needed to create new mitochondria, but it also contributes to quality control by enabling the removal of damaged mitochondria and can facilitate apoptosis during high levels of cellular stress. Mitochondrial fission and fusion processes are both mediated by large guanosine triphosphatases (GTPases). Fission is mediated by dynamin-related protein 1 (DRP1), which is recruited from the cytosol to form spirals around mitochondria that constrict to sever both inner and outer membranes. Fusion between mitochondrial outer membranes is mediated by membrane-anchored dynamin family members named mitofusins MFN1 and MFN2, whereas fusion between mitochondrial inner membranes is mediated by a single dynamin family member called OPA1 mitochondrial dynamin-like GTPase (OPA1) in mammals. Mitochondrial fission and fusion machineries are regulated by proteolysis and posttranslational modifications [49]. The remodeling of the ridges by the ablation of OPA1 would lead to a disturbance in the formation of super complexes and a decrease in respiration [50]. 


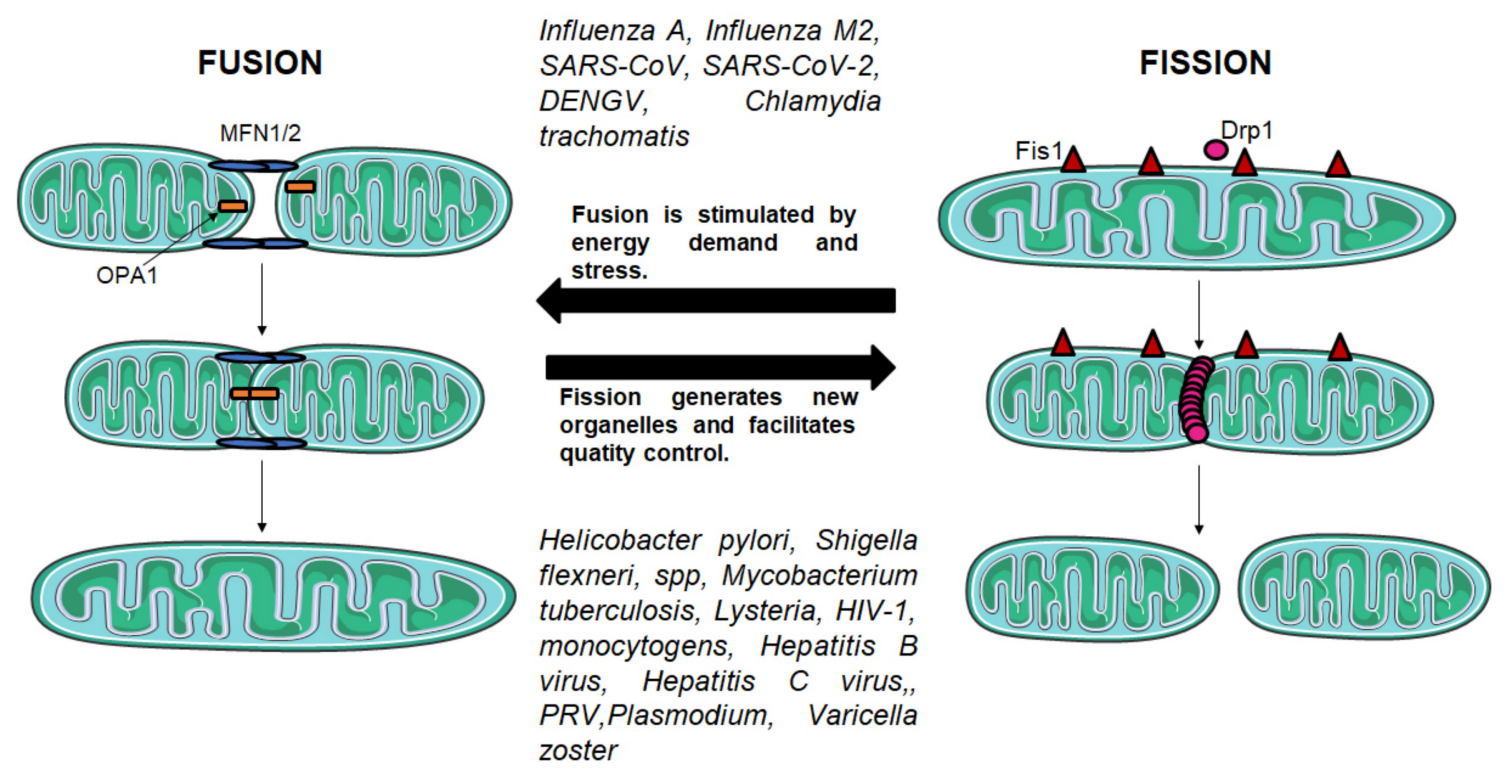

Figure 4. Fusion and fission mechanisms. Fusion and fission mechanisms are important in the regulation of mitochondrial morphology and function. Fission is mediated by DRP1, a GTPase which is recruited from the cytosol by FIS1 to form spirals around mitochondria that constrict both inner and outer membranes. Fusion between mitochondrial outer membranes is mediated by MFN1 and MFN2, whereas fusion between mitochondrial inner membranes is mediated by OPA1.

\subsection{Mitophagy}

Mitophagy is an essential mechanism in the homeostasis of the mitochondrial network because it mediates the removal of defective mitochondria. Two proteins are known to initiate this process: PTEN-induced putative kinase 1 (PINK1) and Parkin [51,52]. Under non-dysfunctional conditions, the PINK1 protein, located at the mitochondrial membrane, is degraded by two proteases, the matrix processing peptidases (MPP) and the presenilin-associated rhomboid like (PARL). However, infection or inflammatory processes can promote depolarization of the mitochondrial membrane, a process known to inhibit the cleavage of PINK1, which leads to the accumulation of PINK1 at the mitochondrial membrane. PINK1-rich membrane promotes activation of Parkin by phosphorylating SER65 in the ubiquitin-like (UBL) domain, promoting parkin-dependent ubiquitination of substrates in the mitochondria [52]. Additionally, PINK1 also phosphorylates ubiquitin monomers at SER65 in the cytosol [53-55], promoting arrangement of ubiquitin chains that will mediate ubiquitination of mitochondrial proteins. Mitochondrial proteins that have been ubiquitinated will bind to autophagy receptors such as optineurin and NDP52 recruited by PINK1 [56] that bind to the microtubule-associated protein 1A/1B-light chain 3 (LC3) protein linked to the phagophore. This will create the mitophagosome, which fuses with the lysosome to destroy the damaged mitochondria [57].

\section{Role of Mitochondria in Inflammation and Infection}

In different ways, mitochondria play a central role in the innate immune response. It is at the center of the inflammatory response in the case of a viral or bacterial infection or in cellular damage. Indeed, in the case of an infection by a pathogenic agent, the microorganisms will be detected by pattern-recognition receptors (PRR) that recognize pathogen-associated molecular patterns (PAMPs), such as flagellins, lipopolysaccharide, mannose, nucleic acids and proteins and the danger-associated molecular motifs (DAMPs) molecules derived from damaged cells pathway (Figure 5). 


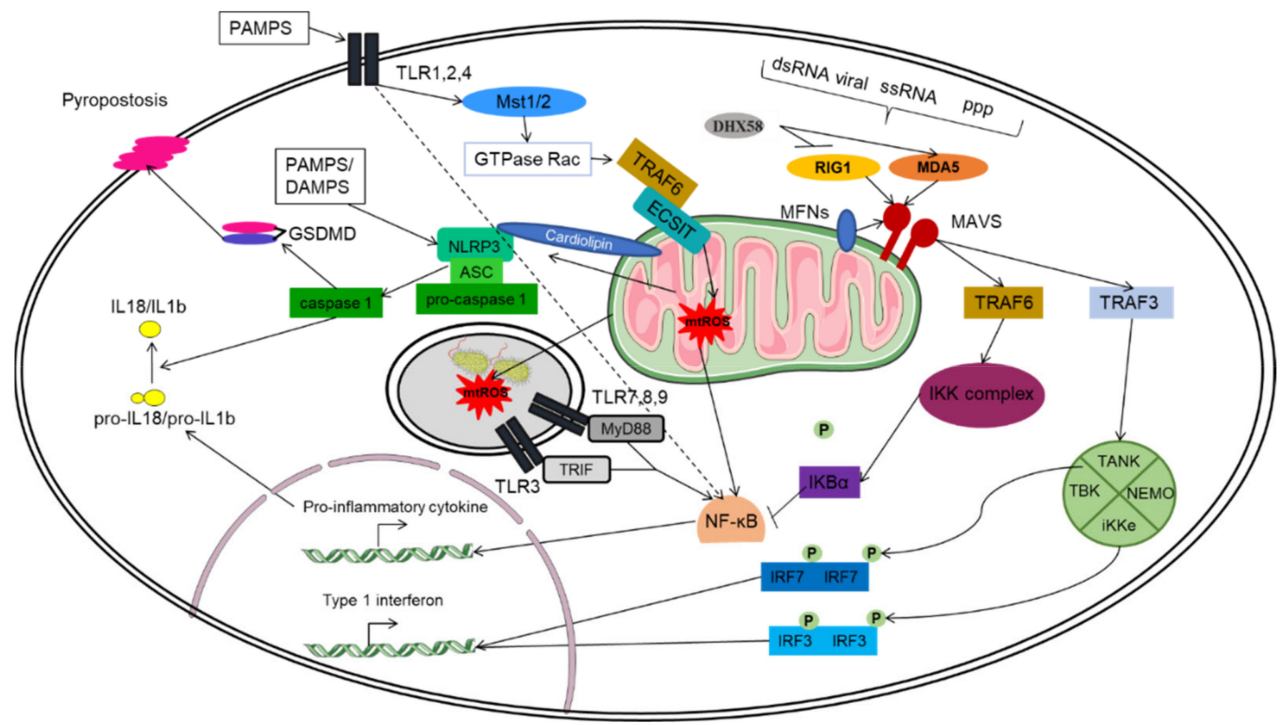

Figure 5. The mitochondria at the center of the RLR, NLR and TLR pathways. The mitochondrion plays an important role in the innate immune response, as it participates in the main pathways involved in the immune response: the TLR, RLR and NLR pathways. The TLR pathway is involved in the antimicrobial response. PAMPs will activate the TLRs. The membrane-spanning TLRs (TLR1, TLR2, TLR4) and endosome-bonded TLRs (TLR3, TLR7, TLR8 and TLR9) are activated and trigger the expression of pro-inflammatory cytokines via the NF-kB pathway. The TLRs activate the kinases Mst1 and Mst2, which activate the GTPase Rac allowing the assembly of the TRAF6-ECSIT complex. The TRAF6 translocates to the mitochondria and binds to ECSIT, forming the TRAF6-ECSIT complex, which lead to an increase in mitochondrial ROS (mtROS) production as well as the proximity of the mitochondria and the phagosome. The bacteria in the phagosome will be destroyed by the action of mtROS. The RLR pathway is involved in antiviral response. Different PAMPs such as dsRNA, ssRNA and 5'-triphosphate (ppp) will activate two cytoplasmic PRRs, RIG-1 and MDA5. These PRR are regulated by DHX58, where DHX58 positively regulates MDA5 and negatively regulates RIG-1. After the interaction with DHX58/RIG1/MDA5, MAVS is activated by recruiting different proteins, such as TRAF3 and TRAF6. The interaction between MAVS and the MFN1 and MFN2 fusion proteins (MFNs) are essential for RLR pathway signaling. TRAF3 will activate the TANK/NEMO/iKKe/TBK complex, which will phosphorylate IRF7 and IRF3 dimers, allowing their translocation into the nucleus and their binding to ISRE sequences at the promoters of type I IFN-regulated genes, while TRAF6 will activate the IKK complex. This complex activates NF-kB by phosphorylating its inhibitor IKB $\alpha$. Once activated, NF-kB translocates to the nucleus to induce the expression of pro-inflammatory genes. The NLR pathway is involved in a mechanism for fighting infection and cellular damage. The main complex of this pathway is the NLRP3 inflammasome. The inflammasome is a multiprotein complex containing ASC, pro-caspase 1 and NLRP3. The activation of NLRP3 inflammasome is done both on transcriptional and post translational levels. The first is related to TLR activation and production of pro-IL1b and pro-IL18. The second signal is based on the detection of PAMPs and DAMPs that leads to NLRP3 oligomerization and interaction with ASC. Then, ASC recruits pro-caspase 1 via the CARD domain. Once caspase 1 is activated, it cleaves the pro-IL1b and pro-IL18 which will allow the release of these inflammatory cytokines in the extracellular milieu. In addition, caspase 1 cleaves Gsdmd, which will allow pore creation at the plasma membrane and pyroptosis. In addition, MAVS is also necessary for the recruitment of NLRP3 in mitochondrial membranes. Cardiolipin and mtROS promote the activation of NLRP3 inflammasome.

There are four families of PRRs, toll-like receptors TLRs [58], (NOD)-like receptors (NLRs), C-type lectin receptors (CLRs) and retinoic acid-inducible gene I (RIG-I)-like receptors (RLRs). Each PRR allows the secretion of type I interferon and pro-inflammatory cytokines via NF-kB [59]. 
In the case of viral infection, the mitochondria play a role in the detection of the virus. Indeed, the MAVS (mitochondrial antiviral signaling protein), a protein located at the outer membrane of the mitochondria, plays a central role of the RLR receptor signaling pathway, which leads to the production of pro-inflammatory cytokines and type 1 interferon (IFN) [60-63]. In fact, two cytoplasmic PRR, the retinoic-acid-inducible gene (RIG-1) and melanoma differentiation-associated protein 5 (MDA5) recognize different PAMPS such as dsRNA viral or 5'-triphosphate (ppp) and single-stranded RNA (ssRNA) [64]. These PRR are regulated by DExH-Box Helicase 58 (DHX58) [65], where DHX58 positively regulates MDA5 and negatively regulates RIG-1 [66]. RIG-1 and MAD5 are cytosolic helicases with an ATPase activity. The C-terminal links with viral RNA and the $\mathrm{N}$-terminal binds to two caspase recruitment domains (CARD) in tandem to link with MAVS protein [64-68]. After the interaction with DHX58, MAVS is activated and forms the MAVS signalosome by recruiting different proteins, such as TNF receptor associated factors TRAF3 and TRAF6 [69,70]. The recruitment of TRAF3 and TRAF6 induces expression of type I IFN and NF-kB pathway activation. Indeed, TRAF3 activates the TANK/NEMO/iKKe/TBK complex, which will phosphorylate IRF7 and IRF3 dimers, allowing their translocation into the nucleus and their binding to ISRE sequences at the promoters of type I IFN-regulated genes. On the other hand, TRAF6 activates the IKK complex. This complex activates NF-kB by phosphorylating its inhibitor IKB $\alpha$. Once activated, NF-kB translocate to the nucleus to induce the expression of pro-inflammatory genes [71].

In addition, mitochondrial dynamics regulate the RLR signaling pathway. The mitochondria are a dynamic network that change in response to biological demands through fusion and fission. It was shown that interaction between MAVS and MFNs protein as well as mitochondrial fusion is necessary in the RLR signaling pathway [72]. Indeed, mitochondrial elongation and increased RLR response was observed after DRP1 and FIS1 inhibition by shRNA and siRNA in Hela cells infected by sendai virus (SeV) strain H4 [72]. Furthermore, knockout of MFN1 and MFN2 in mouse embryo fibroblasts (MEFs) reduced the RLR response against Sendai virus $(\mathrm{SeV})$ and encephalomyocarditis virus (EMCV) [73]. So, disturbances of mitochondria fission and fusion affect the RLR-mediated response to virus.

The electron transport chain of the oxidative phosphorylation produces ROS, mainly in the complexes I and III, and to a lesser extent in complex II [74]. ROS are essential in antiviral signaling and antibacterial response. In the case of antiviral signaling, several observations suggest that increased cellular ROS amplifies the RLR response. It was shown that deletion of the autophagic vesicle formation gene ATG5 in mouse embryonic fibroblasts (MEFs) lead to an increase in ROS production and mitochondrial damage as well as increase in the RLR signaling $[75,76]$. In addition, authors described that production of type I interferon through RLR signaling is diminished by antioxidants the N-acetyl-Lcysteine (NAC) and propyl gallate (PG) [76]. These experiments show that constitutive levels of ROS are used by RLR for signaling. In addition, blockage of Complex I with rotenone in WT and ATG5 mutated cells increased mitochondrial ROS and RLR response against vesicular stomatitis virus infection (RIG-I stimulation) or Poly I:C transfection (MDA-5 stimulation).

The importance of ROS in the antibacterial response was shown via the ablation of regulatory protein Uncoupling Protein 2 (UCP2]. Studies have shown that electron leakage during ETC produces superoxides that diffuse to the internal membrane, oxidizing phospholipids and generating 4-hydroxynonenal [4HNE). The 4HNE activates the UCP that will uncouple the mitochondrial respiratory chain, therefore reducing the protonic force and the formation of superoxide [77]. Knockout of UCP2 in mice model was associated with higher mitochondrial ROS (mtROS) production, increased production of type I interferon and proinflammatory cytokines and thus increased antibacterial response [78,79]. LPS-stimulated macrophages had decreased UCP2 expression, which led to an increase in mtROS and higher production of pro-inflammatory cytokine and type I interferon [80]. Mitochondrial ROS is thought to participate in oxidative bursting in activated macrophages and these data revealed the important role of mitochondria-generated ROS in fighting infection. 
Macrophages and dendritic cells eliminate microorganisms through phagocytosis. The proximity between phagosomes and mitochondria allows mtROS to cross the phagosome to eliminate the pathogen. After the activation of TLRs (TLR1, TLR2 and TLR4) by a pathogen, the increase of mtROS, as well as the approximation of mitochondria and phagosomes are done through the activation of the kinases Mst1 and Mst2. These kinases activate the GTPase Rac, which allows the assembly of the TRAF6-ECSIT complex [81]. Indeed, the TRAF6 factor translocates to the mitochondria and binds to ECSIT, playing an important role in complex I assembly. Complexing with TRACF6 will lead to an increase in mtROS production as well as the proximity of the mitochondria and the phagosome [82].

Mitochondria are also involved in an essential mechanism for fighting infection and cellular damage: the NRLP3 inflammasome. This mechanism allows the recruitment of inflammatory cells to the site of infection by allowing the secretion of IL-1b but also an induction of a TH1 response with an increase in cytotoxic activity with the secretion of IL-18 [83,84]. In addition to these two actions, the inflammasome is involved in a particular cell death: pyroptosis. This inflammatory cell death depends on the activation of the inflammasome and has the role of eliminating intracellular bacteria before they proliferate too much, as well as inducing a local inflammatory phenomenon with the recruitment of other immune cells [85-87].

The inflammasome is a multiprotein complex containing an adapter apoptosis-associated speck-like protein containing a C-terminal caspase recruitment domain (ASC), pro-caspase 1 and the specific member of the NOD-like receptor protein 3 (NLRP3) [88]. The activation of NLRP3 inflammasome is done on transcriptional and post translational levels. The first is related to activation of toll-like receptors (TLR) and production of pro-IL1b and pro-IL18 [89,90]. The second signal is based on the detection of PAMPs and danger-associated molecular motifs (DAMPs) that drive NLRP3 oligomerization and interaction with the ASC adaptor through the pyrin domain (PYD). Then, ASC recruits pro-caspase1 via the CARD domain. Once caspase 1 is activated, it cleaves the pro-IL1b and pro-IL18 which releases these inflammatory cytokines in circulation [88,91-93]. In addition, caspase 1 cleaves gasdermin D (Gsdmd), allowing the formation of plasma membrane pores and pyroptosis [94].

The mitochondria are very important in NLRP3 activation. Indeed, MAVS is necessary for the recruitment of NLRP3 in mitochondrial membranes [95]. The phospholipid cardiolipin translocates from the inner to the outer membrane of the mitochondria to bind to NLRP3 and promote its activation [96]. In addition, the mitochondrial ROS also participates in NLRP3 activation [97-99].

Infection by a pathogen is not the only cause of inflammation; indeed, tissue damage activates various inflammatory mechanisms through DAMPs. Since mitochondria have prokaryotic origins [4], it can be assumed that prokaryotic and mitochondrial components have similarities that may give them a high DAMP potential [100]. Indeed, a study has demonstrated the activation of the immune system by accumulation of mtDNA in the cytosol results in an antiviral immune response [101,102] and the oxidation of mtDNA leads inflammasome activation [101,103]. The cardiolipin is also considered a mitochondrial DAMP [104]. Moreover, as mentioned above, it allows the activation of the NLRP3 inflammasome [96].

In summary, the mitochondria are important to trigger the RLR, NLR or TLR-related innate immune response against virus, bacteria, fungi or sterile tissue damage.

\section{Mitochondrial Bioenergetics and Dynamics in Infectious Diseases}

The mitochondria play both bioenergetics and biosynthetic roles, since ATP and components of several macromolecules, such as amino acids, lipids and nucleotides, are generated in these organelle [105]. Mitochondria are also hubs for innate immune signaling against viruses and bacteria, thus involved in immunological response. Infectious pathogens have evolved mechanisms to target and modulate mitochondria to successfully replicate inside eukaryotic cells. The pathogen's ability to exploit mitochondria is under close scrutiny over the past few years [106]. Considering the pleiotropic functions of mito- 
chondria, it is not surprising that pathogens exploit the mitochondrial key roles during the infection affecting the oxidative phosphorylation complex and mitochondrial network. In this section, we briefly described how some pathogens affect mitochondria dynamics and energetics (Table 1).

Table 1. Effect caused by bacteria, protozoan and viruses on mitochondria bioenergetics and dynamics.

\begin{tabular}{|c|c|c|}
\hline Organism & Pathogen & Effect on Mitochondria \\
\hline \multirow{21}{*}{ Virus } & PRV & Fission [107] \\
\hline & DENGV & Fusion [108] \\
\hline & & Reduced mitochondria content $[109,110]$ \\
\hline & EBV & Reduced $\Delta \psi \mathrm{m}$, reduced ATP [111] \\
\hline & & Increased ROS and MMPT opening [111] \\
\hline & Hepatitis B virus & Fission, perinuclear distribution [112] \\
\hline & Hepatitis $C$ virus & Fission, perinuclear distribution [113] \\
\hline & & Increased OXPHOS $[114,115]$ \\
\hline & HIV-1 & Decreased $\Delta \psi \mathrm{m}[116]$ \\
\hline & & Fission, perinuclear distribution $[116,117]$ \\
\hline & Influenza A & Fusion and increased ROS [118] \\
\hline & Influenza M2 & Fusion and increased ROS [119] \\
\hline & SARS-CoV & Fusion [120] \\
\hline & & Fusion [121-123] \\
\hline & SARS-CoV-2 & Increased ROS [124] \\
\hline & HRV & Decreased ROS [125] \\
\hline & & Reduced cristae [126] \\
\hline & $\mathrm{HPV}$ & Reduced $\Delta \psi \mathrm{m}[127]$ \\
\hline & & Increased ROS $[126,128]$ \\
\hline & & Fission [129] \\
\hline & Varicella zoster & Warburg effect [129-131] \\
\hline \multirow{10}{*}{ Bacteria } & & Fission [132] \\
\hline & Listeria monocytogenes & DRP1-independent fission $[133,134]$ \\
\hline & Legionella pneumophila & $\begin{array}{l}\text { Reduced ATP, reduced oxygen consumption } \\
\text { [135] }\end{array}$ \\
\hline & Chlamudia trachomatic & Fusion [136] \\
\hline & Cntamyata tracnomatts & ROS production $[137,138]$ \\
\hline & Helicobacter pylori & Fission [139] \\
\hline & Shigella flexneri & Fission $[140,141]$ \\
\hline & & Fission, perinuclear distribution $[137,138]$ \\
\hline & Mycobacterium tuberculosis & Reduced $\Delta \psi \mathrm{m}[142,143]$ \\
\hline & & Increased $\Delta \psi \mathrm{m}$ and ATP [143] \\
\hline \multirow{16}{*}{ Protozoa } & & Decreased OXPHOS activity $[144,145]$ \\
\hline & & Reduced activity of GPx, GSH and MnSOD \\
\hline & Trypanosoma cruzi & {$[146,147]$} \\
\hline & & Increased ROS [148-150] \\
\hline & & Increased oxidative stress $[151,152]$ \\
\hline & & $\begin{array}{c}\text { Increased basal respiration, proton leak and ATP } \\
\text { production [153] }\end{array}$ \\
\hline & & Impaired $\Delta \psi \mathrm{m}$, increased ROS [154] \\
\hline & Plasmodium spp. & Fission and apoptosis [155-157] \\
\hline & & Fission $[158]$ \\
\hline & & Fusion [159] \\
\hline & Toxoplasma gondii & Increased ROS [158] \\
\hline & & Changed metabolism [160] \\
\hline & & OXPHOS [161] \\
\hline & & Decreased OXPHOS proteins [158] \\
\hline & & Impaired $\Delta \psi \mathrm{m}[162]$ \\
\hline & Leishmania spp. & Metabolic shift [163] \\
\hline
\end{tabular}




\subsection{Viruses}

Viral infection is extremely dependent on the host cell machinery to successfully replicate and the mechanism by which viruses affect mitochondria is closely related to the virus type [164]. For example, infection with the alpha herpes virus Varicella zoster virus (VZV) was shown to induce persistent mitochondrial swelling and fragmentation throughout the time course of VZV infection, yet the mechanisms involved remain unknown [129]. Some studies suggest that VZV triggers the Warburg effect, i.e., metabolic shift from oxidative phosphorylation to glycolysis which regulates mitochondrial activity and thus promotes cell resistance to apoptosis and viral spread [129-131]. A similar study showed that alphaherpesviruses HSV-1 (herpes simplex virus type 1) and PRV (pseudorabies virus) also disrupt mitochondrial motility and morphology while promoting accumulation of intracellular $\mathrm{Ca}^{2+}$ in neurons, important mechanisms for viral growth and spread [107].

Infection with Epstein-Barr virus (EBV), an oncovirus associated with Burkitt lymphoma, reduces mitochondria content in differentiating monocytes [109], remodels B cell mitochondria by targeting the mitochondrial 1-Carbon pathway involved in the synthesis of purine, thymidylate and glutathione [110] and also induces mitochondria swelling, cyclophilin D dependent mitochondrial membrane permeabilization transition (MMPT), decreased mitochondrial membrane potential $(\Delta \psi \mathrm{m})$ and ATP, increased ROS production and mitophagy and reduced apoptosis [111]. Additionally, proteins of human papillomavirus (HPV) interact with mitochondria, promoting detachment of mitochondria from microtubules, reducing or eliminating cristae compartment, resulting in decreased $\Delta \psi \mathrm{m}$, increased production of mtROS, oxidative stress and DNA damage [126-128,165].

One of the most common effects in mitochondria caused by viruses is related to mitochondrial fragmentation. In order to suppress virus-induced apoptosis, hepatitis B (HBV) and hepatitis $\mathrm{C}(\mathrm{HCV})$ viruses modulate mitochondrial dynamics towards fission by the activation of dynamin-related protein 1 (DRP1) and mitochondrial fission factor (MFF), as well as increase in the expression of genes related to ubiquitin-proteasome system that mediates the targeting of proteins for degradation, such as LC3B, PARKIN and PINK1, thus activating mitophagy $[112,113,166]$.

The infection with human immunodeficiency viruses HIV-1 also perturbs mitochondrial dynamics and bioenergetics. For example, mitochondria promote sustained calcium influx to support synaptic signaling and play an important role in the formation of the immunological synapse (IS), i.e., the nano-scale interface (gap) between T-cells [167]. The virological synapse of HIV-1 shares similar features with IS and the HIV-1 promotes mitochondria polarization and enhanced oxidative phosphorylation, thus facilitating HIV-1 replication and cell-to-cell transmission [114,115]. Moreover, the release of HIV proteins gp120 and Tat was shown to promote mitochondrial fragmentation by enhancing translocation of DRP1, decreased $\Delta \psi \mathrm{m}$ and perinuclear aggregation, generally followed by accumulation of ROS in the nucleus of human primary neurons [116,117].

While the aforementioned virus mediates mitochondrial fragmentation through activation of DRP1, dengue virus (DENGV), on the contrary, induces mitochondria elongation and reduced mitochondrial fragmentation via membrane-associated protein NS4B and suppression of DRP1 phosphorylation [108]. Similarly, infection with SARS-CoV and the novel SARS-CoV-2 virus was reported to induce mitochondria elongation through proteasomal degradation of DRP1 or decreased expression of mitochondrial fission promoting genes SOCS6 and MTFP1 [120,122,123,168]. SARS-CoV-2 spike protein peptides interacts with $\alpha 7$ nicotinic acetylcholine receptors (nAChRs) preventing mitochondria to release cytochrome $\mathrm{C}$, avoiding mitochondria-driven apoptosis in a glioblastoma-derived cell line [169]. A study showed that COVID-19 patients had elevated mitochondrial ROS associated with tissue injury [124]. Moreover, the Influenza A virus and Influenza M2 virus induced mitochondrial elongation and fusion, production of mitochondrial ROS, driving innate immune inflammation which favors viral pathogenesis $[118,119]$. On the other hand, infection with the human rhinoviruses (HRV), which cause common cold and lower airways diseases, suppress mitochondrial ROS during infection to induce a transitory 
barrier-protective metabolic state that becomes exhausted as the infection progresses and leads to cellular damage [125]. I.e., while for some viruses, mitochondrial fragmentation and mitophagy are important mechanisms for viral replication because they favor cell survival and evasion of apoptosis, while for other viruses the maintenance of mitochondrial structure is essential to provide energetic provision to the infected cell before the virus replication cycle is complete [169].

\subsection{Bacteria}

In bacterial infections, host cells produce ROS as a defense mechanism to impair metabolism and growth of intracellular bacteria by inflicting damage to the pathogen's lipids, proteins, and nucleic acids. However, some bacteria can benefit from ROS and thus sustain intracellular production of ROS to grow [170]. Mitochondrial dynamics play important roles in the pathogeny of bacteria. Mitochondrial fission, for instance, is an important element to eliminate infected cells and reduce cell-to-cell-spreading, thus modulation of apoptosis can support bacterial dissemination [140,171].

Chlamydia trachomatis is the most common sexually transmitted bacterium and can cause trachoma (blindness) and pneumoniae respiratory infection. A study showed that $C$. trachomatis indeed augments production of ROS through a mechanism that involves direct NOX-dependent ROS production and translocation of NLRX1 (member of the Nod-like receptor family) to mitochondria and for optimal chlamydial growth and replication $[137,138]$. Moreover, $C$. trachomatis requires mitochondrial ATP for normal development and consequently authors suggest that they preserve mitochondrial integrity through the microRNA miR-30c-5p-dependent inhibition of DRP1-mediated mitochondrial fission [136].

Infection with the diarrhea-causing bacteria Shigella flexneri was shown to drive mitochondria into fragmentation through DRP1 which allows the bacteria to evade the intracellular entrapment in cages-like structures composed of septins assembled by mitochondria [141]. Mitochondrial fission mediated by DRP1 is also an important preceding factor for vacuolating cytotoxin A (VacA) induced cell death of Helicobacter pylori infection [139]. Similarly, Legionella pneumophilla, which causes Legionnaire's disease (an atypical pneumonia), controls mitochondrial dynamics to destabilize mitochondrial bioenergetics of infected cells via fission protein DRP1, causing mitochondrial fragmentation independent of cell death, dampening of mitochondrial respiration and promoting the Warburg-like phenotype in the infected cell that favors bacterial replication [135].

Conversely, some bacteria induce mitochondrial fragmentation independently of DRP1. Bacterial infection with Lysteria monocytogenes can cause severe sepsis, meningitis, or encephalitis and a study showed that this infection causes a transient $\mathrm{Ca}^{2+}$-dependent fragmentation of the mitochondrial networks through the secreted toxin listeriolysin $\mathrm{O}$ (LLO), impairing $\Delta \psi \mathrm{m}$, mitochondrial respiration and decrease in intracellular content of ATP $[133,134]$. Moreover, L. monocytogenes increases the abundance of Mic10, a key component of the mitochondrial contact site and cristae organizing system (MICOS) in an LLO-dependent manner initiating mitochondrial fission and host cell infection [132].

Infection with Mycobacterium tuberculosis (Mtb), the causative agent of tuberculosis, has two phases, an early non-pathogenic phase and a pathogenic phase [172]. During the non-pathogenic phase, Mtb induces mitochondria fusion and robust activation of $\Delta \psi \mathrm{m}$ and ATP synthesis to inhibit apoptosis and sustain survival of the bacteria [143]. While the onset of the pathogenic phase is characterized by mitochondrial remodeling with induction of an irreversible MMPT following disruption of mitochondrial outer membrane (MOM), loss of $\Delta \psi \mathrm{m}$, cytochrome $\mathrm{C}$ release and consequently necrosis $[142,173]$.

\subsection{Protozoa}

Different from viruses and bacteria, protozoans carry their own mitochondria, and the mitochondrial dynamics are directly linked to the parasite life cycle. A recent review has documented the aspects of protozoan's mitochondria and mitochondrion-related organelles 
dynamics [174]. Here, we summarized findings of how host's mitochondria bioenergetics and dynamics are affected during protozoan infection.

Infection with the protozoan Trypanosoma cruzi can cause Chagas disease cardiomyopathy and megacolon $[175,176]$. Studies have shown that T. cruzi can elicit oxidative stress in host tissue by promoting increase in the production of cellular and mitochondrial ROS [148-150]. In addition, T. cruzi decreases the enzymatic activities of mitochondrial respiratory complexes [144,145], increased basal respiration, proton leak and ATP production [153]. Moreover, hearts of chronically T.cruzi-infected animals and Chagas disease patients have decreased activity of cytosolic glutathione peroxidase (GPx) and GSH and this was associated with decreased expression and activity of the mitochondrial antioxidant enzyme manganase superoxide dismutase (MnSOD) $[146,147]$. The combination of increased intracellular ROS and inadequate anti-oxidative response was described as crucial for T. cruzi survival, since T. cruzi takes advantage and uses ROS as "fuel" to grow, due to disturbed iron metabolism [177]. Mitochondria-associated damage has been observed in cardiomyocytes infected by T. cruzi, such as defects of the respiratory chain and enhanced oxidative stress [151,152]. A recent study showed that mice deficient for the mitochondrial folding protein $\mathrm{CyPD}$, which is essential for mitochondrial permeability transition pore opening, had inhibited collapse of the $\Delta \psi \mathrm{m}$ and reduced severity of parasite aggression and spread of T. cruzi [178]. Recent studies revealed that T. cruzi tissue tropism is controlled by key metabolic pathways, such as glycolysis, fatty acid oxidation, acylcarnitine metabolism and amino acid catabolism [179,180]. Moreover, interactions between host-parasitemicrobiome regulate the intensity of infection and progression of chagasic gastrointestinal disease [179]. T. cruzi can benefit from these pathways to growth and/or to evade antiparasitic immune response [180].

Toxoplasma gondii, the causative agent of toxoplasmosis, is known to cause encephalitis, retinitis and miscarriage [181] Data reported an increase of mitochondria fragmentation of human fibroblasts cells infected with the $T$. gondii and these mitochondria were recruited to the parasitophorous vacuole $[158,182]$. In addition, infected cells had metabolic perturbations of mitochondrial glycolysis [160] and OXPHOS complex [161], as well as increase of mitochondrial ROS, changes the amount of OXPHOS components and many other mitochondrial-related proteins $[158,183]$. In addition, host mitochondria fuse during $T$. gondii infection to limit fatty acids (FAs) uptake [159]. A proteomic study conducted by Blank and colleagues showed that $T$. gondii manipulation of host mitochondria requires association with key mitochondrial proteins, such as TOM70 and HSPA9 [184]. Another study showed that $T$. gondii unique dense granule antigen (GRA8) interacts with host proteins involved in mitochondria activation, ATP5A1-SIRT3 signaling pathways, thus contributing to a so-called mitochondrial metabolic resuscitation in order to maintain and regulate cellular metabolism and consequently parasite survival [166].

Plasmodium is a genus of protozoans that cause malaria, a highly inflammatory disease, being Plasmodium falciparum the deadliest in humans $[185,186]$. Shivappagowdar and co-workers provided new insights on malaria pathogenesis. They identified that the P. falciparum pore-forming proteins (PFPs) have damaging effects to primary vascular endothelial cells, where exposed cells had impaired $\Delta \psi \mathrm{m}$, increased ROS and apoptosis [154]. In a similar approach, it was shown that infection by Plasmodium yoelii makes host hepatocytes susceptible to mitochondria-initiated apoptosis, through a mechanism that involve increased expression of the proapoptotic Bcl-2, leading to mitochondrial fission and apoptosis [155-157].

Leishmania spp. parasites cause cutaneous or visceral leishmaniosis, a neglected tropical disease that can cause skin ulcers, swelling of the spleen and liver. The infection with Leishmania donovani was reported to disrupt miRNA turnover in macrophages, causing mitochondrial depolarization through induced expression of the OXPHOS uncoupler uncoupling protein 2 (UCP2) [162]. This infection also affects the ER-mitochondria tethering mediated by mitofusin 2 [162]. Another study showed that macrophages infected with $L$. infantum switched from an early glycolytic metabolism to an oxidative phosphorylation, and this metabolic deviation requires SIRT1 and LKB1/AMPK [163]. 
Collectively, these studies revealed an intrinsic relationship between parasites and host mitochondria. In general, the infection triggers an initial protective effect to mitochondrial dynamics and host cell bioenergetics to sustain parasite proliferation and survival. Afterwards, the infection triggers a damaging response, by eliciting cell death and parasite release. To understand the different phases of infection and develop mitochondrial-target therapies is a promising strategy to ameliorate or cure infectious diseases.

\section{Mito-Nuclear Crosstalk and Infection}

Infection by pathogens changes the mitochondrial metabolic and oxidative profile of infected cells. One of the outcomes on mitochondria is fragmentation and excessive ROS production, which may lead to a decreased mitochondrial mass inside the host cell. The mitochondria cannot be made de novo and they are encoded by the both mitochondrial and nuclear DNA, thus the mito-nuclear communication is essential for the proper coordination of mitochondrial biogenesis. A dynamic regulatory system able to respond to the now challenging infectious environment is crucial [187]. Several studies already reported that dysregulation of the crosstalk between the nucleus and the mitochondria has an impact in the disease progression of different etiologies, such as cancer, diabetes and heart failure.

The mitonuclear regulation signaling can be both anterograde (nucleus to mitochondria) and retrograde (mitochondria to nucleus) and it is coordinated by transcription factors and coactivators that regulate the expression of both mitochondrial and nuclear genes in response to an infectious insult [188]. Metabolic or other damages that occur within mitochondria culminate in dysregulation of several nuclear genes through the retrograde signaling. The proteins belonging to the peroxisome-proliferator activated receptor coactivator-1 family (PGC1] are reported to be the master regulators of mitochondrial biogenesis, oxidative phosphorylation and response to oxidative stress in humans [189]. The amount of PGC-1a is closely correlated with the number of mitochondria and deficiency in PGC1a has been reported to cause mitochondrial dysfunction, metabolic derangements and cell death [190-193]. A recent study showed that sepsis induced by cecal ligation and puncture (CLP) in mice decreased the expression of Ppargcla (encoding PGC1a), and this reduction was linked with decreased number of total mitochondria, increased in the percentage of injured mitochondria and impaired oxidative phosphorylation [194]. Pharmacological activation of PGC1a promotes defense against human rhinovirus infections (HRV) [125]. Suliman, HB and coworkers showed that nuclear accumulation of PGC-1 was a transcriptional response to lipopolysaccharide (LPS) administration in rat heart, which caused reduced mtDNA copy number and increased oxidative stress [195]. Other study showed that the Pseudomonas aeruginosa metabolite 2-amino acetophenone (2-AA) downregulated the expression of PGC1b and PPARy and this was associated with mitochondrial dysfunction in skeletal muscle and depletion of ATP synthesis in mice [196].

Activation of PGC1a is mediated by AMP-activated protein kinase (AMPK), which is considered a guardian of the cell metabolism and mitochondrial homeostasis [197]. Under cellular stress, AMPK phosphorylates specific enzymes such as mitofusins to control the dynamics of mitochondrial fusion and fission, autophagy-related protein 9 (ATG9) and serine/threonine-protein kinase ULK1 proteins to modulate autophagy and mitophagy, phospholipase D1 (PLD1) and thioredoxin-interacting protein (TXNIP) to control glucose uptake, acetyl-CoA carboxylases ACC1 and ACC2 of fatty-acid and sterol synthesis and lipid $\beta$-oxidation, PGC1a to regulate mitochondrial biogenesis, among others [197]. AMPK can either inhibit anabolism favoring a decrease in ATP consumption or stimulate ATP generation by catabolic mechanisms. Proper activation of AMPK-PGC1a pathway is required for antimicrobial host defense of several pathogens [198].

The PGC-1a response also included interaction with the redox-regulated nuclear respiratory factors NRF1 and NRF2. These factors mediate the coordination between nuclear and mitochondrial genomes by regulating the expression of several nuclear-encoded ETC proteins and by activating the mitochondrial transcription factor (TFAM), thus involved in the mitochondrial-encoded cytochrome $\mathrm{C}$ oxidase (COX) subunits and mitochondrial DNA 
replication $[199,200]$. This communication reveals an integration of multiple transcriptional regulatory pathways to sustain homeostasis in a tissue specific way [201]. During infection, studies reported altered expression of NRF1 and/or NRF2 in viral infection with DENGV [202,203], Influenza A virus [114], HIV [204,205], HSV-1 [206], EBV [109,207-209], SARS-CoV-2 [210] and human T-cell leukemia virus type 1 (HTLV-1) [211]. Similarly, bacterial infection was shown to modulate the expression of NRF1/NRF2, such as infection with Staphylococcus aureus [212-214] and Escherichia coli [215]. The expression of NRF2 was also modulated after protozoan infection with Plasmodium spp. [216], Leishmania spp. [217], Toxoplasma gondii [218] and Entamoeba histolytica [219]. T. cruzi infection decreased the protein expression of Nrf1 and Nrf2 in infected cardiomyocytes [220], and overexpression of Nrf2 was correlated with reduced parasitism [221].

Mitochondrial intermediate metabolites mediate epigenetic modifications, and these modifications are affected during infectious processes. For example, the mitochondrial acetyl-CoA metabolism drives histone acetylation, leading to chromatin opening and gene regulation in response to nutrient availability, metabolic reprogramming, signaling cues or stress [222]. Indeed, in vitro depletion of mtDNA caused chronic mitochondrial dysfunction, decreased enzymatic activity of histone acetyltransferases (HATs) and consequently reduced the acetylation of histones H3K9 and H3K27 [223]. A review highlighted that DNA acetylation is a crucial factor that affects the infection capacity of herpesvirus, such as human cytomegalovirus (HCMV) and Epstein-Barr virus (EBV) [224]. Bacterial infection of the human monocytic cell line THP-1 with $M$. tuberculosis infection decreased histone acetylation at the endogenous high-affinity Fc-gamma receptor (FCGR1A) promoter, which resulted in impaired response to IFN- $\gamma$ [225]. L. monocytogenes induced deacetylation of H3K18 by mediating nuclear translocation of the deacetylase SIRT2 in vivo and in vitro [226]. Inhibition of histone deacetylase was shown to enhance mitochondrial reactive oxygen and to reduce significantly the intracellular bacterial loads of human macrophages infected with Salmonella enterica serovar Typhimurium and Escherichia coli [227]. Several metabolic pathways generate mitochondrial acetyl-CoA, including pyruvate conversion to acetyl-CoA by the pyruvate dehydrogenase complex (PDC), amino acid metabolism, conversion of acetate to acetyl-CoA by mitochondrial acyl-CoA synthetase short chain family member 1 (ACSS1), ketone body metabolism and fatty acid $\beta$-oxidation [226]. Mitochondria is also involved in the regulation of DNA and histone methylation. Mitochondria-TCA-generated $\alpha$-Ketoglutarate $(\alpha-K G)$ is an important cofactor of the lysine demethylase 6B (KDM6B), histone demethylases (HDM) and TET DNA methylases, while fumarate, succinate and 2-hydroxyglutarate [2-HG) are inhibitors of TET [228]. Chromatin remodeling through a KDM6B-dependent demethylation of H3L27 within the IL-11 promoter was reported to facilitate the p65-NF-kB interaction, which "fine-tuned" cellular response against Streptococcus pneumoniae [229]. Pathogen-induced metabolic disturbances can, therefore, affect the mitochondrial metabolism, misbalance the production of mitochondrial metabolites involved in chromatin remodeling culminating in improper immune response.

In general, the proper coordination between mitochondria, metabolite generation and activation of nuclear genes PGC1a/NRF1 and NRF2 is crucial to sustain cell survival. Dysregulation in the mito-nuclear communication provoked by infectious pathogens triggers oxidative stress, mtDNA oxidation and mtDNA replication impairment. Consequently, therapeutic intervention targeting molecules involved in the mito-nuclear crosstalk might be beneficial for the treatment of infectious diseases.

\section{Therapeutic Strategies Targeting Mitochondria to Fight Infection}

As described during the review, the role of mitochondria plays a crucial role during infection and inflammation. The role of mitochondria in these biological processes makes this organelle a good promising candidate for the development of therapeutic strategies. Indeed, several studies already investigated mitochondria-targeted therapeutic strategies 
focusing on processes such as mitophagy, ROS production or inflammasome to improve response to pathogenic infection (Table 2).

Table 2. Therapeutic strategies targeting mitochondria in inflammatory and infectious disease models.

\begin{tabular}{|c|c|c|}
\hline Mechanism & Compound & Infection or Inflammatory Disease Model \\
\hline Induce Mitophagy & $\begin{array}{l}\text { Urolithin A } \\
\text { Kinetin triphosphate }\end{array}$ & $\begin{array}{c}\text { Colitis in mice [230] } \\
\text { Diabetes in mice [231] } \\
\text { Cardiomyopathy in rats [232] } \\
\text { Neuronal tissue disease models [220,233] } \\
\text { Cellular model of Parkinson's disease [234] }\end{array}$ \\
\hline Limit mtROS & $\begin{array}{c}\text { MitoTEMPO } \\
\text { Mitoquinone mesylate (MitoQ) }\end{array}$ & $\begin{array}{c}\text { Influenza A virus infection in mice [118] } \\
\text { Cell lines infected with respiratory syncytial virus [235] } \\
\text { Patients with chronic hepatitis C virus [236] }\end{array}$ \\
\hline $\begin{array}{l}\text { Inhibit NLRP3 inflammasome } \\
\text { Reduce the secretion and expression of inflammatory } \\
\text { factors: inhibit NK- } \mathrm{kb} \text { pathways, TNF- } \alpha \text {, IL6 and ROS }\end{array}$ & $\begin{array}{l}\text { Mitoquinone mesylate (MitoQ) } \\
\qquad \text { MCC950 }\end{array}$ & $\begin{array}{c}\text { Colitis in mice [237] } \\
\text { Class II clinical trials for Alzheimer's disease, } \\
\text { Parkinson's disease and motor neuron disease [238] } \\
\text { Mice infected with mycobacterium tuberculosis bacteria [239] } \\
\text { Rabbit models of acute pharyngitis [240] } \\
\text { In colorectal cancer patients [241] }\end{array}$ \\
\hline $\begin{array}{l}\text { Inhibit mitochondrial fission: inhibit Drp1 and limit } \\
\text { mtROS }\end{array}$ & $\begin{array}{l}\text { Melatonin and mdivi-1 } \\
\text { P110 }\end{array}$ & $\begin{array}{c}\text { Diabetic cardiomyopathy in diabetic mice [242] } \\
\text { In vitro in LPS-treated H9C2 cardiomyocytes and in vivo in septic } \\
\text { cardiomyopathy mice models [243] } \\
\text { In vitro model of Parkinson's disease [244] }\end{array}$ \\
\hline $\begin{array}{l}\text { Artificial mitochondrial transfer } \\
\text { Mitoception [245] }\end{array}$ & & $\begin{array}{c}\text { Transfer mitochondria from human mesenchymal stem cells to T } \\
\text { cells, and that this transfer would reprogram the cells to promote } \\
\text { the induction of tregs [246] } \\
\text { Rabbit model of ischemia-reperfusion injury of the heart [247] } \\
\text { Rats models of ischemia-reperfusion injury of the liver [248] } \\
\text { Rats models of ischemic stress in the brain [249] }\end{array}$ \\
\hline
\end{tabular}

\subsection{Mitophagy}

The mitophagy is the quality control of the mitochondria network by eliminating defective mitochondria. Infection by microorganisms causes inflammation and mitochondrial damage, such as a decrease in membrane potential, ATP production, fission of mitochondria and disrupted of mitochondrial network. Many components of the mitochondria such as mtROS, mtDNA can be perceived by the cell as inflammatory signals [100].

Controlling mitophagy could be a good strategy to limit excessive inflammation and restore homeostasis in case of infection. For example, infection with single-stranded RNA (ssRNA) viruses such as HIV was shown to inhibit mitophagy [250]. ssRNAs also activate the inflammasome, which lead to an increased activation of the inflammasome and increase mitochondrial damage. This was shown in a study in microglia, which resulted in neurotoxicity [251]. Activation of mitophagy limits mitochondrial damage and cell death caused by HIV infection [252]. Many infectious diseases cause excessive inflammatory responses, such as Chagas disease or sepsis and activation of mitophagy is a control mechanism of excessive inflammation by reducing the amount of damaged mitochondria. Some authors are modulating mitophagy in disease models. A study conducted by D'Amico and co-workers showed that Urolithin A (UA), a gut microbiomederived natural compound, increased mitophagy and reduced pro-inflammatory cytokine production and decreased inflammation [253]. In addition, activation of autophagy by UA had beneficial effects in different chronic inflammation pathologies such as colitis in mice [230], diabetes in mice [231], cardiomyopathy in rats [232] and neuronal tissue disease models $[220,233]$. Additionally, in a cellular model of Parkinson's disease, a neo-substrate of the PINK1 enzyme has been identified. Indeed, this new substrate, kinetin triphosphate (KTP), a small molecule analogous to ATP, will have a higher catalytic efficiency than its endogenous substrate ATP. This will allow in vitro in this cellular model of Parkinson's disease to increase the enzymatic activity of PINK1 and to increase mitophagy [234].

\subsection{Mitochondrial ROS}

Another possible therapeutic strategy is to limit the generation of mtROS. In order to decrease the production of mtROS, treatments with mitochondrial antioxidants are under 
investigation. The mitochondria-targeted antioxidant MitoTEMPO has been tested in mice in a model of influenza A virus infection [118]. Infection by the influenza virus promoted mtROS production, but intranasal treatment with mitoTEMPO reduced the amount of mtROS in the lungs, which improved mouse survival [194]. It was also shown that human embryonic kidney cells and human alveolar epithelial cell lines treated with the mtROSspecific antioxidant mitoquinone mesylate (MitoQ) and infected with respiratory syncytial virus had lower mtROS production, which limited viral infection [235]. The antioxidant MitoQ also reduces necroinflammation in the liver of patients with chronic hepatitis C virus [236]. The use of these different mtROS-specific antioxidants in these infection models is evidence that mtROS limitation is a potential therapeutic strategy for infectious diseases.

In addition, the natural phenolic compound resveratrol is repeatedly reported as an antioxidant treatment. This natural antioxidant was shown to ameliorate inflammation by reducing the secretion and the expression of pro-inflammatory factors, such as molecules of the NF- $\mathrm{KB}$ pathway, TNF- $\alpha$, IL6 and ROS production [240]. The role of resveratrol as strong anti-inflammatory agent on infectious disease was reported in a study that investigated acute pharyngitis in rabbit model [240] and in patients with colorectal cancer [241].

\subsection{Inflammasome}

Limiting the activation of the inflammasome could help to limit the inflammation and to improve the phenotype of the patients with chronic inflammation diseases such as Chagas disease [254], hepatitis C virus [255], HIV [256], uncontrollable inflammation such as sepsis [121,256] or the development and progression of cancer [257]. In a colitis mouse model, it was shown that MitoQ suppressed NLRP3 inflammasome activation [237]. MCC950 is a molecule that inhibits both the canonical and non-canonical inflammasome pathways, preventing its formation [258-260]. This molecule was shown to reduce neuroinflammation in study models of Alzheimer's disease [238,261]. The use of MCC950 is expected to enter in a phase II clinical trial for Alzheimer's disease and other neurological disorders such as Parkinson's disease and motor neuron disease to assess if this molecule can decrease neuroinflammation [238]. The molecule MCC950 was also tested in bone marrow cells derived from mice infected with Mycobacterium tuberculosis and results showed that MCC950 blocked the NLRP3 inflammasome and reduced bacterial survival [239].

Targeting the NLRP3 inflammasome is a therapeutic strategy against diseases with significant inflammation to consider. It would even be interesting to study it in relation to the current COVID-19 epidemic [262].

\subsection{Mitochondrial Dynamics}

The mitochondrial dynamics sustain cell homeostasis and the mitochondrial network. The fusion mechanism is important for ATP production to meet the energy needs of the cell. While the fission mechanism is important in the generation of new mitochondria and the quality control of these. As described in previous sections, the pathogens can manipulate mitochondrial dynamics to favor their intracellular replication. Many of them will cause mitochondrial fission. Some studies described molecules that modulate the mitochondrial fission process. Indeed, the molecule P110 is a specific inhibitor of the interaction of DRP1/FIS1 [243]. The P110 was shown to mediate mitochondria dysfunction by effectively inhibiting the interaction DRP1/FIS1 interaction in in vitro and in vivo models of septic cardiomyopathy [243]. Moreover, P110 diminished neurotoxicity by inhibiting aberrant mitochondrial fission in neuron cell lines model of Parkinson's disease [244]. Additional molecules are known to inhibit DRP1-mediated mitochondrial fission, such as melatonin and mdivi-1. Inhibition of fission by melatonin and mdivi-1 was shown to limit mtROS production in diabetic mice by a mechanism that involves the SIRT1-PGC1 $\alpha$ pathway [242], which could also have beneficial impact on infectious disease models. 


\subsection{Artificial Mitochondrial Transfer}

A newly studied therapeutic strategy is the cell-to-cell mitochondria transfer, especially between cells of different types. This cell-to-cell transfer of mitochondria was first shown between human mesenchymal cells and mitochondria-deficient cancer cells. The transferred mitochondria re-established a mitochondrial network in the mitochondriadeficient cancer cells [250]. In inflammation, mitochondrial damage accumulates and amplifies the inflammatory response, so it might be thought that transferring healthy mitochondria would regulate the inflammation. A team demonstrated that the regulation of $\mathrm{T}$ cells by mitochondrial transfer was possible and that it could attenuate inflammation [246]. Indeed, they used a technique called mitoception [245] which allows the transfer of mitochondria from human mesenchymal stem cells to $T$ cells and that this transfer reprogramed the cells to promote the induction of Tregs, thus regulating the inflammation by activating on the expression of FOXP3, IL2RA, CTLA4 et TGF $\beta 1$ factors those that will increase CD25+ FoxP3+ population. [246]. Autologous mitochondria transfer is currently being studied extensively in the reduction of ischemia after reperfusion. Two in vivo studies reported that autologous mitochondria transfer in rabbit protected the heart from ischemia-reperfusion injury [247,263]. Mitochondria transfer also resulted in the reduction of ischemic reperfusion injury in rat's liver [248] and brain [249]. Further studies are necessary to investigate if mitochondria transfer has potential to be a therapeutic strategy to improve mitochondria function in chronic inflammatory and/or infectious diseases.

\section{Conclusions}

In this review, we explored how the major mechanisms involved in the mitochondrial bioenergetics and dynamics are modulated by inflammation and pathogen infection. We also addressed the therapeutic strategies that are underway. The host cell mitochondria manipulation by pathogens is an effective evolutionary mechanism that allows the pathogens to effectively infect, survive and proliferate inside the potentially harsh intracellular environment.

It has become clear that chronic inflammatory and infectious diseases affect mitochondria by either disrupting the mitochondria networks or by promoting excessive, uncontrolled production of reactive oxygen species. Mitochondria dysfunction and oxidative stress are mediators of improper immune response, tissue disruption and organ failure and thus are perfect targets for disease control. With the ever-increasing demand of new therapeutic strategies, the mitochondria's role in disease needs to be further explored as it has shown to have great potential for the development of refined therapy for viral, bacterial and protozoan infections and chronic inflammatory diseases.

Author Contributions: Writing, reviewing and editing: P.A., E.C.-N., C.C. and J.P.S.N. All authors have read and agreed to the published version of the manuscript.

Funding: This work was supported by the Institut National de la Santé et de la Recherche Médicale (INSERM); the Aix-Marseille University (grant number: AMIDEX “International_2018" MITOMUTCHAGAS); the French Agency for Research (Agence Nationale de la Recherche-ANR (grant numbers: "Br-Fr-Chagas", "landscardio"); the CNPq (Brazilian Council for Scientific and Technological Development); and the FAPESP (São Paulo State Research Funding Agency Brazil (grant numbers: 2013/50302-3, 2014/50890-5]; the National Institutes of Health/USA (grant numbers: 2P50 AI098461-02 and 2U19AI098461-06]. This work was founded by the Inserm Cross-Cutting Project GOLD. This project has received funding from the Excellence Initiative of Aix-Marseille University - A*Midex a French "Investissements d'Avenir programme"- Institute MarMaRa AMX-19-IET-007. JPSN was a recipient of a MarMaRa fellowship. ECN is recipient of productivity awards by CNPq. The funders did not play any role in the study design, data collection and analysis, decision to publish, or preparation of the manuscript.

Institutional Review Board Statement: Not applicable.

Informed Consent Statement: Not applicable.

Data Availability Statement: Not applicable. 
Conflicts of Interest: The authors declare no conflict of interest.

\section{References}

1. Mileykovskaya, E.; Dowhan, W. Cardiolipin membrane domains in prokaryotes and eukaryotes. Biochim. Biophys. Acta (BBA) Biomembr. 2009, 1788, 2084-2091. [CrossRef] [PubMed]

2. Nass, S.; Nass, M.M. Intramitochondrial Fibers with DNA Characteristics. Ii. Enzymatic and Other Hydrolytic Treatments. J. Cell Biol. 1963, 19, 613-629. [CrossRef] [PubMed]

3. Sagan, L. On the origin of mitosing cells. J. Theor. Biol. 1967, 14, 225-274. [CrossRef]

4. Martin, W.; Müller, M. The hydrogen hypothesis for the first eukaryote. Nature 1998, 392, 37-41. [CrossRef] [PubMed]

5. Gould, S.B.; Garg, S.G.; Martin, W.F. Bacterial Vesicle Secretion and the Evolutionary Origin of the Eukaryotic Endomembrane System. Trends Microbiol. 2016, 24, 525-534. [CrossRef]

6. Anderson, S.; Bankier, A.T.; Barrell, B.G.; De Bruijn, M.H.L.; Coulson, A.R.; Drouin, J.; Eperon, I.; Nierlich, D.P.; Roe, B.A.; Sanger, F.; et al. Sequence and organization of the human mitochondrial genome. Nature 1981, 290, 457-465. [CrossRef]

7. Gray, M.; Sankoff, D.; Cedergren, R.J. On the evolutionary descent of organisms and organelles: A global phylogeny based on a highly conserved structural core in small subunit ribosomal RNA. Nucleic Acids Res. 1984, 12, 5837-5852. [CrossRef]

8. Cedergren, R.; Gray, M.W.; Abel, Y.; Sankoff, D. The evolutionary relationships among known life forms. J. Mol. Evol. 1988, 28, 98-112. [CrossRef]

9. Gray, M.; Cedergren, R.; Abel, Y.; Sankoff, D. On the evolutionary origin of the plant mitochondrion and its genome. Proc. Natl. Acad. Sci. USA 1989, 86, 2267-2271. [CrossRef]

10. Yang, D.; Oyaizu, Y.; Oyaizu, H.; Olsen, G.J.; Woese, C.R. Mitochondrial origins. Proc. Natl. Acad. Sci. USA 1985, 82, $4443-4447$. [CrossRef]

11. Andersson, S.; Kurland, C. Ancient and recent horizontal transfer events: The origins of Mitochondria. APMIS 1998, 106, 5-14. [CrossRef] [PubMed]

12. Andersson, S.G.; Kurland, C.G. Reductive evolution of resident genomes. Trends Microbiol. 1998, 6, 263-268. [CrossRef]

13. Andersson, D.I.; Hughes, D. Muller's ratchet decreases fitness of a DNA-based microbe. Proc. Natl. Acad. Sci. USA 1996, 93, 906-907. [CrossRef] [PubMed]

14. Andersson, G.E.; Kurland, C.G. An extreme codon preference strategy: Codon reassignment. Mol. Biol. Evol. 1991, 8, 530-544. [CrossRef] [PubMed]

15. Andersson, S.G.; Kurland, C.G. Origins of mitochondria and hydrogenases. Curr. Opin. Microbiol. 1999, 2, 535-541. [CrossRef]

16. Berg, O.G.; Kurland, C.G. Why Mitochondrial Genes are Most Often Found in Nuclei. Mol. Biol. Evol. 2000, 17, 951-961. [CrossRef] [PubMed]

17. Karlberg, O.; Canback, B.; Kurland, C.G.; Andersson, S.G. The dual origin of the yeast mitochondrial proteome. Yeast 2000, 17, 170-187. [CrossRef]

18. Kimura, M. Rare variant alleles in the light of the neutral theory. Mol. Biol. Evol. 1983, 1, 84-93. [CrossRef]

19. Kerr, J.F.; Wyllie, A.H.; Currie, A.R. Apoptosis: A basic biological phenomenon with wide-ranging implications in tissue kinetics. Br. J. Cancer 1972, 26, 239-257. [CrossRef] [PubMed]

20. Kroemer, G. Mitochondrial implication in apoptosis. Towards an endosymbiont hypothesis of apoptosis evolution. Cell Death Differ. 1997, 4, 443-456. [CrossRef]

21. Klim, J.; Gładki, A.; Kucharczyk, R.; Zielenkiewicz, U.; Kaczanowski, S. Ancestral State Reconstruction of the Apoptosis Machinery in the Common Ancestor of Eukaryotes. G3 Genes Genom. Genet. 2018, 8, 2121-2134. [CrossRef] [PubMed]

22. Bar-Yaacov, D.; Blumberg, A.; Mishmar, D. Mitochondrial-nuclear co-evolution and its effects on OXPHOS activity and regula-tion. Biochim. Biophys. Acta. 2012, 1819, 1107-1111. [CrossRef] [PubMed]

23. Barrientos, A.; Kenyon, L.; Moraes, C.T. Human xenomitochondrial cybrids. Cellular models of mitochondrial complex I deficiency. J. Biol. Chem. 1998, 273, 14210-14217. [CrossRef] [PubMed]

24. Kenyon, L.; Moraes, C.T. Expanding the functional human mitochondrial DNA database by the establishment of primate xenomitochondrial cybrids. Proc. Natl. Acad. Sci. USA 1997, 94, 9131-9135. [CrossRef] [PubMed]

25. Friedman, J.R.; Nunnari, J. Mitochondrial form and function. Nature 2014, 505, 335-343. [CrossRef] [PubMed]

26. Lane, N.; Martin, W.F. The energetics of genome complexity. Nature 2010, 467, 929-934. [CrossRef]

27. Martin, W.; Koonin, E.V. Introns and the origin of nucleus-cytosol compartmentalization. Nature 2006, 440, 41-45. [CrossRef]

28. Mitchell, P.J. Coupling of Phosphorylation to Electron and Hydrogen Transfer by a Chemi-Osmotic type of Mechanism. Nature 1961, 191, 144-148. [CrossRef]

29. Martinez-Reyes, I.; Chandel, N.S. Mitochondrial TCA cycle metabolites control physiology and disease. Nat. Commun. 2020, 11, 102. [CrossRef]

30. Wirth, C.; Brandt, U.; Hunte, C.; Zickermann, V. Structure and function of mitochondrial complex I. Biochim. Biophys. Acta (BBA) Bioenerg. 2016, 1857, 902-914. [CrossRef]

31. Neupane, P.; Bhuju, S.; Thapa, N.; Bhattarai, H.K. ATP Synthase: Structure, Function and Inhibition. Biomol. Concepts 2019, 10, 1-10. [CrossRef]

32. Hatefi, Y. The mitochondrial electron transport and oxidative phosphorylation system. Annu. Rev. Biochem. 1985, 54, 1015-1069. [CrossRef] [PubMed] 
33. Schagger, H.; Pfeiffer, K. Supercomplexes in the respiratory chains of yeast and mammalian mitochondria. EMBO J. 2000, 19, 1777-1783. [CrossRef] [PubMed]

34. Shinzawa-Itoh, K.; Shimomura, H.; Yanagisawa, S.; Shimada, S.; Takahashi, R.; Oosaki, M.; Ogura, T.; Tsukihara, T. Purification of Active Respiratory Supercomplex from Bovine Heart Mitochondria Enables Functional Studies. J. Biol. Chem. 2016, 291, 4178-4184. [CrossRef] [PubMed]

35. Moreno-Sanchez, R.; Bravo, C.; Westerhoff, H.V. Determining and understanding the control of flux. An illustration in submitochondrial particles of how to validate schemes of metabolic control. Eur. J. Biochem. 1999, 264, 427-433. [CrossRef]

36. Bianchi, C.; Genova, M.L.; Castelli, G.P.; Lenaz, G. The mitochondrial respiratory chain is partially organized in a super-complex assembly: Kinetic evidence using flux control analysis. J. Biol. Chem. 2004, 279, 36562-36569. [CrossRef]

37. Greggio, C.; Jha, P.; Kulkarni, S.S.; Lagarrigue, S.; Broskey, N.T.; Boutant, M.; Wang, X.; Alonso, S.C.; Ofori, E.; Auwerx, J.; et al. Enhanced Respiratory Chain Supercomplex For-mation in Response to Exercise in Human Skeletal Muscle. Cell Metab. 2017, 25, 301-311. [CrossRef]

38. Acin-Perez, R.; Bayona-Bafaluy, M.P.; Silva, P.F.; Loshuertos, R.M.; Pérez-Martos, A.; Bruno, C.; Moraes, C.T.; Enríquez, J.A. Respiratory Complex III Is Required to Maintain Complex I in Mammalian Mitochondria. Mol. Cell 2004, 13, 805-815. [CrossRef]

39. Diaz, F.; Fukui, H.; Garcia, S.; Moraes, C.T. Cytochrome c Oxidase Is Required for the Assembly/Stability of Respiratory Complex I in Mouse Fibroblasts. Mol. Cell. Biol. 2006, 26, 4872-4881. [CrossRef]

40. Alkhaja, A.K.; Jans, D.C.; Nikolov, M.; Vukotic, M.; Lytovchenko, O.; Ludewig, F.; Schliebs, W.; Riedel, D.; Urlaub, H.; Jakobs, S.; et al. MINOS1 is a conserved component of mitofilin complexes and required for mitochondrial function and cristae organization. Mol. Biol. Cell 2012, 23, 247-257. [CrossRef] [PubMed]

41. Hoppins, S.; Collins, S.R.; Cassidy-Stone, A.; Hummel, E.; DeVay, R.M.; Lackner, L.L.; Westermann, B.; Schuldiner, M.; Weissman, J.S.; Nunnari, J. A mitochondrial-focused genetic interaction map reveals a scaffold-like complex required for inner membrane organization in mitochondria. J. Cell Biol. 2011, 195, 323-340. [CrossRef] [PubMed]

42. Von der Malsburg, K.; Müller, J.M.; Bohnert, M.; Oeljeklaus, S.; Kwiatkowska, P.; Becker, T.; Loniewska-Lwowska, A.; Wiese, S.; Rao, S.; Milenkovic, D.; et al. Dual role of mitofilin in mito-chondrial membrane organization and protein biogenesis. Dev. Cell. 2011, 21, 694-707. [CrossRef]

43. Barbot, M.; Jans, D.C.; Schulz, C.; Denkert, N.; Kroppen, B.; Hoppert, M.; Jakobs, S.; Meinecke, M. Mic10 Oligomerizes to Bend Mitochondrial Inner Membranes at Cristae Junctions. Cell Metab. 2015, 21, 756-763. [CrossRef] [PubMed]

44. Bohnert, M.; Zerbes, R.M.; Davies, K.; Mühleip, A.; Rampelt, H.; Horvath, S.E.; Boenke, T.; Kram, A.; Perschil, I.; Veenhuis, M.; et al. Central Role of Mic10 in the Mitochondrial Contact Site and Cristae Organizing System. Cell Metab. 2015, 21, 747-755. [CrossRef] [PubMed]

45. Davies, K.M.; Anselmi, C.; Wittig, I.; Faraldo-Gómez, J.D.; Kühlbrandt, W. Structure of the yeast F1Fo-ATP synthase dimer and its role in shaping the mitochondrial cristae. Proc. Natl. Acad. Sci. USA 2012, 109, 13602-13607. [CrossRef] [PubMed]

46. Strauss, M.; Hofhaus, G.; Schröder, R.R.; Kühlbrandt, W. Dimer ribbons of ATP synthase shape the inner mitochondrial membrane. EMBO J. 2008, 27, 1154-1160. [CrossRef]

47. Davies, K.; Strauss, M.; Daum, B.; Kief, J.H.; Osiewacz, H.D.; Rycovska, A.; Zickermann, V.; Kühlbrandt, W. Macromolecular organization of ATP synthase and complex I in whole mitochondria. Proc. Natl. Acad. Sci. USA 2011, 108, 14121-14126. [CrossRef]

48. Wilkens, V.; Kohl, W.; Busch, K. Restricted diffusion of OXPHOS complexes in dynamic mitochondria delays their exchange between cristae and engenders a transitory mosaic distribution. J. Cell Sci. 2013, 126, 103-116. [CrossRef]

49. Hoppins, S.; Lackner, L.; Nunnari, J. The Machines that Divide and Fuse Mitochondria. Annu. Rev. Biochem. 2007, 76, 751-780. [CrossRef]

50. Cogliati, S.; Frezza, C.; Soriano, M.E.; Varanita, T.; Quintana-Cabrera, R.; Corrado, M.; Cipolat, S.; Costa, V.; Casarin, A.; Gomes, L.C.; et al. Mitochondrial Cristae Shape Determines Respiratory Chain Supercomplexes Assembly and Respiratory Efficiency. Cell 2013, 155, 160-171. [CrossRef]

51. Matsuda, N.; Sato, S.; Shiba, K.; Okatsu, K.; Saisho, K.; Gautier, C.A.; Sou, Y.-S.; Saiki, S.; Kawajiri, S.; Sato, F.; et al. PINK1 stabilized by mitochondrial depolarization recruits Parkin to damaged mitochondria and activates latent Parkin for mitophagy. $J$. Cell Biol. 2010, 189, 211-221. [CrossRef]

52. Narendra, D.; Tanaka, A.; Suen, D.F.; Youle, R.J. Parkin is recruited selectively to impaired mitochondria and promotes their au-tophagy. J. Cell Biol. 2008, 183, 795-803. [CrossRef]

53. Shiba-Fukushima, K.; Arano, T.; Matsumoto, G.; Inoshita, T.; Yoshida, S.; Ishihama, Y.; Ryu, K.-Y.; Nukina, N.; Hattori, N.; Imai, Y. Phosphorylation of Mitochondrial Polyubiquitin by PINK1 Promotes Parkin Mitochondrial Tethering. PLoS Genet. 2014, 10, e1004861. [CrossRef] [PubMed]

54. Kane, L.A.; Lazarou, M.; Fogel, A.I.; Li, Y.; Yamano, K.; Sarraf, S.; Banerjee, S.; Youle, R.J. PINK1 phosphorylates ubiquitin to activate Parkin E3 ubiquitin ligase activity. J. Cell Biol. 2014, 205, 143-153. [CrossRef] [PubMed]

55. Koyano, F.; Okatsu, K.; Kosako, H.; Tamura, Y.; Go, E.; Kimura, M.; Kimura, Y.; Tsuchiya, H.; Yoshihara, H.; Hirokawa, T.; et al. Ubiquitin is phosphorylated by PINK1 to activate parkin. Nature 2014, 510, 162-166. [CrossRef] [PubMed]

56. Lazarou, M.; Sliter, D.A.; Kane, L.A.; Sarraf, S.; Wang, C.; Burman, J.L.; Sideris, D.P.; Fogel, A.I.; Youle, R.J. The ubiquitin kinase PINK1 recruits autophagy receptors to induce mitophagy. Nat. Cell Biol. 2015, 524, 309-314. [CrossRef]

57. Johansen, T.; Lamark, T. Selective Autophagy: ATG8 Family Proteins, LIR Motifs and Cargo Receptors. J. Mol. Biol. 2020, 432, 80-103. [CrossRef] 
58. Kawai, T.; Akira, S. TLR signaling. Semin. Immunol. 2007, 19, 24-32. [CrossRef]

59. Hatada, E.N.; Krappmann, D.; Scheidereit, C. NF-kappaB and the innate immune response. Curr. Opin. Immunol. 2000, $12,52-58$. [CrossRef]

60. Seth, R.B.; Sun, L.; Ea, C.K.; Chen, Z.J. Identification and characterization of MAVS, a mitochondrial antiviral signaling protein that activates NF-kappaB and IRF 3. Cell 2005, 122, 669-682. [CrossRef] [PubMed]

61. Xu, L.G.; Wang, Y.Y.; Han, K.J.; Li, L.Y.; Zhai, Z.; Shu, H.B. VISA is an adapter protein required for virus-triggered IFN-beta signaling. Mol Cell. 2005, 19, 727-740. [CrossRef] [PubMed]

62. Meylan, E.; Curran, J.; Hofmann, K.; Moradpour, D.; Binder, M.; Bartenschlager, R.; Tschopp, J. Cardif is an adaptor protein in the RIG-I antiviral pathway and is targeted by hepatitis C virus. Nature 2005, 437, 1167-1172. [CrossRef] [PubMed]

63. Kawai, T.; Takahashi, K.; Sato, S.; Coban, C.; Kumar, H.; Kato, H.; Ishii, K.; Takeuchi, O.; Akira, S. IPS-1, an adaptor triggering RIG-I- and Mda5-mediated type I interferon induction. Nat. Immunol. 2005, 6, 981-988. [CrossRef] [PubMed]

64. Jiang, F.; Ramanathan, A.; Miller, M.T.; Tang, G.-Q.; Gale, M.; Patel, S.S.; Marcotrigiano, J. Structural basis of RNA recognition and activation by innate immune receptor RIG-I. Nature 2011, 479, 423-427. [CrossRef] [PubMed]

65. Hei, L.; Zhong, J. Faculty Opinions recommendation of Laboratory of genetics and physiology 2 (LGP2) plays an essential role in hepatitis C virus infection-induced interferon responses. Hepatology 2017, 65, 1478-1491. [CrossRef]

66. Uchikawa, E.; Lethier, M.; Malet, H.; Brunel, J.; Gerlier, D.; Cusack, S. Structural Analysis of dsRNA Binding to Anti-viral Pattern Recognition Receptors LGP2 and MDA5. Mol. Cell 2016, 62, 586-602. [CrossRef]

67. Liu, Y.; Olagnier, D.; Lin, R. Host and Viral Modulation of RIG-I-Mediated Antiviral Immunity. Front. Immunol. 2016, 7, 662. [CrossRef]

68. Tait, S.; Green, D.R. Mitochondria and cell signalling. J. Cell Sci. 2012, 125, 807-815. [CrossRef] [PubMed]

69. Biacchesi, S.; LeBerre, M.; Lamoureux, A.; Louise, Y.; Lauret, E.; Boudinot, P.; Breémont, M. Mitochondrial Antiviral Signaling Protein Plays a Major Role in Induction of the Fish Innate Immune Response against RNA and DNA Viruses. J. Virol. 2009, 83, 7815-7827. [CrossRef] [PubMed]

70. Vazquez, C.; Horner, S.M. MAVS Coordination of Antiviral Innate Immunity. J. Virol. 2015, 89, 6974-6977. [CrossRef] [PubMed]

71. Belgnaoui, S.M.; Paz, S.; Hiscott, J. Orchestrating the interferon antiviral response through the mitochondrial antiviral signaling (MAVS) adapter. Curr. Opin. Immunol. 2011, 23, 564-572. [CrossRef] [PubMed]

72. Castanier, C.; Garcin, D.; Vazquez, A.; Arnoult, D. Mitochondrial dynamics regulate the RIG-I-like receptor antiviral pathway. EMBO Rep. 2010, 11, 133-138. [CrossRef] [PubMed]

73. Koshiba, T.; Yasukawa, K.; Yanagi, Y.; Kawabata, S.-I. Mitochondrial Membrane Potential Is Required for MAVS-Mediated Antiviral Signaling. Sci. Signal. 2011, 4, ra7. [CrossRef] [PubMed]

74. Brand, M.D. The sites and topology of mitochondrial superoxide production. Exp. Gerontol. 2010, 45, 466-472. [CrossRef] [PubMed]

75. Jounai, N.; Takeshita, F.; Kobiyama, K.; Sawano, A.; Miyawaki, A.; Xin, K.-Q.; Ishii, K.; Kawai, T.; Akira, S.; Suzuki, K.; et al. The Atg5 Atg12 conjugate associates with innate antiviral immune responses. Proc. Natl. Acad. Sci. USA 2007, 104, 14050-14055. [CrossRef]

76. Tal, M.; Sasai, M.; Lee, H.K.; Yordy, B.; Shadel, G.S.; Iwasaki, A. Absence of autophagy results in reactive oxygen species-dependent amplification of RLR signaling. Proc. Natl. Acad. Sci. USA 2009, 106, 2770-2775. [CrossRef]

77. Brand, M.D.; Esteves, T.C. Physiological functions of the mitochondrial uncoupling proteins UCP2 and UCP. Cell Metab. 2005, 2, 85-93. [CrossRef]

78. Arsenijevic, D.; Onuma, H.; Pecqueur, C.; Raimbault, S.; Manning, B.S.; Miroux, B.; Couplan, E.; Alves-Guerra, M.-C.; Goubern, M.; Surwit, R.; et al. Disruption of the uncoupling protein-2 gene in mice reveals a role in immunity and reactive oxygen species production. Nat. Genet. 2000, 26, 435-439. [CrossRef]

79. Rousset, S.; Emre, Y.; Join-Lambert, O.; Hurtaud, C.; Ricquier, D.; Cassard, A.-M. The uncoupling protein 2 modulates the cytokine balance in innate immunity. Cytokine 2006, 35, 135-142. [CrossRef]

80. Kizaki, T.; Suzuki, K.; Hitomi, Y.; Taniguchi, N.; Saitoh, D.; Watanabe, K.; Onoé, K.; Day, N.K.; Good, R.A.; Ohno, H. Uncoupling protein 2 plays an important role in nitric oxide production of lipopolysaccharide-stimulated macrophages. Proc. Natl. Acad. Sci. USA 2002, 99, 9392-9397. [CrossRef]

81. Geng, J.; Sun, X.; Wang, P.; Zhang, S.; Wang, X.; Wu, H.; Hong, L.; Xie, C.; Li, X.; Zhao, H.; et al. Kinases Mst1 and Mst2 positively regulate phagocytic induction of reactive oxygen species and bactericidal activity. Nat. Immunol. 2015, 16, 1142-1152. [CrossRef] [PubMed]

82. West, A.P.; Brodsky, I.E.; Rahner, C.; Woo, D.K.; Erdjument-Bromage, H.; Tempst, P.; Walsh, M.C.; Choi, Y.; Shadel, G.S.; Ghosh, S. TLR signalling augments macrophage bactericidal activity through mitochondrial ROS. Nature 2011, 472, 476-480. [CrossRef]

83. Dinarello, C.A. Interleukin-1 in the pathogenesis and treatment of inflammatory diseases. Blood 2011, 117, 3720-3732. [CrossRef] [PubMed]

84. Sahoo, M.; Ceballos-Olvera, I.; Del Barrio, L.; Re, F. Role of the Inflammasome, IL-1 $\beta$, and IL-18 in Bacterial Infections. Sci. World J. 2011, 11, 2037-2050. [CrossRef] [PubMed]

85. Liu, X.; Zhang, Z.; Ruan, J.; Pan, Y.; Magupalli, V.G.; Wu, H.; Lieberman, J. Inflammasome-activated gasdermin D causes pyroptosis by forming membrane pores. Nature 2016, 535, 153-158. [CrossRef]

86. Bergsbaken, T.; Fink, S.; Cookson, B.T. Pyroptosis: Host cell death and inflammation. Nat. Rev. Genet. 2009, 7, 99-109. [CrossRef] 
87. Miao, E.A.; Rajan, J.V.; Aderem, A. Caspase-1-induced pyroptotic cell death. Immunol. Rev. 2011, 243, 206-214. [CrossRef]

88. Jo, E.-K.; Kim, J.K.; Shin, D.-M.; Sasakawa, C. Molecular mechanisms regulating NLRP3 inflammasome activation. Cell. Mol. Immunol. 2015, 13, 148-159. [CrossRef]

89. Hornung, V.; Latz, E. Critical functions of priming and lysosomal damage for NLRP3 activation. Eur. J. Immunol. 2010, 40, 620-623. [CrossRef]

90. Guarda, G.; Zenger, M.; Yazdi, A.S.; Schroder, K.; Ferrero, I.; Menu, P.; Tardivel, A.; Mattmann, C.; Tschopp, J. Differential Expression of NLRP3 among Hematopoietic Cells. J. Immunol. 2011, 186, 2529-2534. [CrossRef]

91. De Nardo, D.; Latz, E. NLRP3 inflammasomes link inflammation and metabolic disease. Trends Immunol. 2011, 32, 373-379. [CrossRef]

92. Davis, B.K.; Wen, H.; Ting, J.P.-Y. The Inflammasome NLRs in Immunity, Inflammation, and Associated Diseases. Annu. Rev. Immunol. 2011, 29, 707-735. [CrossRef]

93. Martinon, F.; Burns, K.; Tschopp, J. The inflammasome: A molecular platform triggering activation of inflammatory caspases and processing of proIL-beta. Mol. Cell. 2002, 10, 417-426. [CrossRef]

94. Shi, J.; Zhao, Y.; Wang, K.; Shi, X.; Wang, Y.; Huang, H.; Zhuang, Y.; Cai, T.; Wang, F.; Shao, F. Cleavage of GSDMD by inflammatory caspases determines pyroptotic cell death. Nature 2015, 526, 660-665. [CrossRef] [PubMed]

95. Subramanian, N.; Natarajan, K.; Clatworthy, M.R.; Wang, Z.; Germain, R.N. The Adaptor MAVS Promotes NLRP3 Mitochondrial Localization and Inflammasome Activation. Cell 2013, 153, 348-361. [CrossRef] [PubMed]

96. Iyer, S.S.; He, Q.; Janczy, J.R.; Elliott, E.; Zhong, Z.; Olivier, A.K.; Sadler, J.J.; Knepper-Adrian, V.; Han, R.; Qiao, L.; et al. Mitochondrial Cardiolipin Is Required for Nlrp3 Inflammasome Activation. Immunity 2013, 39, 311-323. [CrossRef] [PubMed]

97. Zhou, R.; Yazdi, A.S.; Menu, P.; Tschopp, J. A role for mitochondria in NLRP3 inflammasome activation. Nature 2010, 469, $221-225$. [CrossRef]

98. Abais, J.M.; Xia, M.; Zhang, Y.; Boini, K.M.; Li, P.L. Redox regulation of NLRP3 inflammasomes: ROS as trigger or effector? Antioxid. Redox. Signal 2015, 22, 1111-1129. [CrossRef]

99. Kelley, N.; Jeltema, D.; Duan, Y.; He, Y. The NLRP3 Inflammasome: An Overview of Mechanisms of Activation and Regulation. Int. J. Mol. Sci. 2019, 20, 3328. [CrossRef]

100. Dela Cruz, C.S.; Kang, M.J. Mitochondrial dysfunction and damage associated molecular patterns (DAMPs) in chronic inflammatory diseases. Mitochondrion 2018, 41, 37-44. [CrossRef]

101. Riley, J.S.; Tait, S.W. Mitochondrial DNA in inflammation and immunity. EMBO Rep. 2020, 21, e49799. [CrossRef] [PubMed]

102. West, A.P.; Khoury-Hanold, W.; Staron, M.; Tal, M.; Pineda, C.M.; Lang, S.M.; Bestwick, M.; Duguay, B.A.; Raimundo, N.; MacDuff, D.A.; et al. Mitochondrial DNA stress primes the antiviral innate immune response. Nature 2015, 520, 553-557. [CrossRef] [PubMed]

103. Shimada, K.; Crother, T.; Karlin, J.; Dagvadorj, J.; Chiba, N.; Chen, S.; Ramanujan, V.K.; Wolf, A.J.; Vergnes, L.; Ojcius, D.; et al. Oxidized Mitochondrial DNA Activates the NLRP3 Inflammasome during Apoptosis. Immunity 2012, 36, 401-414. [CrossRef] [PubMed]

104. Claypool, S.M.; Koehler, C.M. The complexity of cardiolipin in health and disease. Trends Biochem. Sci. 2012, 37, 32-41. [CrossRef]

105. Weinberg, S.; Sena, L.A.; Chandel, N.S. Mitochondria in the Regulation of Innate and Adaptive Immunity. Immunity 2015, 42, 406-417. [CrossRef] [PubMed]

106. Escoll, P.; Mondino, S.; Rolando, M.; Buchrieser, C. Targeting of host organelles by pathogenic bacteria: A sophisticated subversion strategy. Nat. Rev. Genet. 2015, 14, 5-19. [CrossRef]

107. Kramer, T.; Enquist, L.W. Alphaherpesvirus infection disrupts mitochondrial transport in neurons. Cell Host Microbe 2012, 11, 504-514. [CrossRef]

108. Chatel-Chaix, L.; Cortese, M.; Brey, I.R.; Bender, S.; Neufeldt, C.; Fischl, W.; Scaturro, P.; Schieber, N.; Schwab, Y.; Fischer, B.; et al. Dengue Virus Perturbs Mitochondrial Morphodynamics to Dampen Innate Immune Responses. Cell Host Microbe 2016, 20, 342-356. [CrossRef]

109. Gilardini Montani, M.S.; Santarelli, R.; Granato, M.; Gonnella, R.; Torrisi, M.R.; Faggioni. A.; Cirone, M. EBV reduces autophagy, intracellular ROS and mitochondria to impair monocyte survival and differentiation. Autophagy 2019, 15, 652-667. [CrossRef]

110. Wang, L.W.; Shen, H.; Nobre, L.; Ersing, I.; Paulo, J.A.; Trudeau, S.; Wang, Z.; Smith, N.A.; Ma, Y.; Reinstadler, B.; et al. Epstein-Barr-Virus-Induced One-Carbon Metabolism Drives B Cell Transformation. Cell Metab. 2019, 30, 539-555. [CrossRef]

111. Song, S.; Jiang, Z.; Spezia-Lindner, D.E.; Liang, T.; Xu, C.; Wang, H.; Tian, Y.; Bai, Y. BHRF1 Enhances EBV Mediated Nasopharyngeal Carcinoma Tumorigenesis through Modulating Mitophagy Associated with Mitochondrial Membrane Permeabilization Transition. Cells 2020, 9, 1158. [CrossRef] [PubMed]

112. Kim, S.-J.; Khan, M.; Quan, J.; Till, A.; Subramani, S.; Siddiqui, A. Hepatitis B Virus Disrupts Mitochondrial Dynamics: Induces Fission and Mitophagy to Attenuate Apoptosis. PLoS Pathog. 2013, 9, e1003722. [CrossRef] [PubMed]

113. Kim, S.-J.; Syed, G.; Siddiqui, A. Hepatitis C Virus Induces the Mitochondrial Translocation of Parkin and Subsequent Mitophagy. PLoS Pathog. 2013, 9, e1003285. [CrossRef] [PubMed]

114. Day, E.A.; O'Neill, L.A.J. Targeting mitochondria to beat HIV-1. Nat. Immunol. 2021, 22, 1-2. [CrossRef] [PubMed]

115. Wang, S.F.; Tseng, S.P.; Huang, S.W.; Yen, C.H.; Hong, Y.W.; Chen, M.; Chen, Y.M.A. Mitochondria polarization in the contact regions of vi-rus-infected effector cells during cell-to-cell transmission of HIV-1. AIDS Res. Hum. Retrovir. 2015, 31, 175-176. [CrossRef] 
116. Teodorof-Diedrich, C.; Spector, S.A. Human Immunodeficiency Virus Type 1 gp120 and Tat Induce Mitochondrial Fragmenta-tion and Incomplete Mitophagy in Human Neurons. J. Virol. 2018, 92, 22. [CrossRef]

117. Al-Mehdi, A.-B.; Pastukh, V.V.; Swiger, B.M.; Reed, D.J.; Patel, M.R.; Bardwell, G.C.; Alexeyev, M.F.; Gillespie, M.N. Perinuclear Mitochondrial Clustering Creates an Oxidant-Rich Nuclear Domain Required for Hypoxia-Induced Transcription. Sci. Signal. 2012, 5, ra47. [CrossRef]

118. To, E.E.; Erlich, J.R.; Liong, F.; Luong, R.; Liong, S.; Esaq, F.; Oseghale, O.; Anthony, D.; McQualter, J.; Bozinovski, S.; et al. Mitochondrial Reactive Oxygen Species Contribute to Pathological Inflammation During Influenza A Virus Infection in Mice. Antioxid. Redox. Signal. 2020, 32, 929-942. [CrossRef]

119. Wang, R.; Zhu, Y.; Lin, X.; Ren, C.; Zhao, J.; Wang, F.; Gao, X.; Xiao, R.; Zhao, L.; Chen, H.; et al. Influenza M2 protein regulates MAVS-mediated signaling pathway through interacting with MAVS and increasing ROS production. Autophagy 2019, 15, 1163-1181. [CrossRef]

120. Shi, C.S.; Qi, H.Y.; Boularan, C.; Huang, N.N.; Abu-Asab, M.; Shelhamer, J.H.; Kehrl, J.H. SARS-coronavirus open reading frame-9b sup-presses innate immunity by targeting mitochondria and the MAVS/TRAF3/TRAF6 signalosome. J. Immunol. 2014, 193, 3080-3089. [CrossRef]

121. Jiang, H.; Gong, T.; Zhou, R. The strategies of targeting the NLRP3 inflammasome to treat inflammatory diseases. Adv. Immunol. 2020, 145, 55-93. [PubMed]

122. Mehrzadi, S.; Karimi, M.Y.; Fatemi, A.; Reiter, R.J.; Hosseinzadeh, A. SARS-CoV-2 and other coronaviruses negatively influence mitochondrial quality control: Beneficial effects of melatonin. Pharmacol. Ther. 2021, 224, 107825. [CrossRef] [PubMed]

123. Singh, K.; Chen, Y.C.; Hassanzadeh, S.; Han, K.; Judy, J.T.; Seifuddin, F.; Tunc, I.; Sack, M.N.; Pirooznia, M. Network Analysis and Transcriptome Profiling Identify Autophagic and Mitochondrial Dysfunctions in SARS-CoV-2 Infection. Front. Genet. 2021, 12, 289. [CrossRef]

124. Andargie, T.E.; Tsuji, N.; Seifuddin, F.; Jang, M.K.; Yuen, P.S.; Kong, H.; Tunc, I.; Singh, K.; Charya, A.; Wilkins, K.J.; et al. Cell-free DNA maps COVID-19 tissue injury and risk of death and can cause tissue injury. JCI Insight 2021, 6, 7. [CrossRef] [PubMed]

125. Michi, A.N.; Yipp, B.G.; Dufour, A.; Lopes, F.; Proud, D. PGC-1 $\alpha$ mediates a metabolic host defense response in human airway epithelium during rhinovirus infections. Nat. Commun. 2021, 12, 1-19. [CrossRef]

126. Lai, D.; Tan, C.L.; Gunaratne, J.; Quek, L.S.; Nei, W.L.; Thierry, F.; Bellanger, S. Localization of HPV-18 E2 at Mitochondrial Membranes Induces ROS Release and Modulates Host Cell Metabolism. PLoS ONE 2013, 8, e75625. [CrossRef] [PubMed]

127. Raj, K.; Berguerand, S.; Southern, S.; Doorbar, J.; Beard, P. E1 empty set E4 protein of human papillomavirus type 16 associates with mitochondria. J. Virol. 2004, 78, 7199-7207. [CrossRef] [PubMed]

128. Cruz-Gregorio, A.; Manzo-Merino, J.; Gonzaléz-García, M.C.; Pedraza-Chaverri, J.; Medina-Campos, O.N.; Valverde, M.; Rojas, E.; Rodríguez-Sastre, M.A.; Garcia-Cuellar, C.M.; Lizano, M. Human Papillomavirus Types 16 and 18 Early-expressed Proteins Differentially Modulate the Cellular Redox State and DNA Damage. Int. J. Biol. Sci. 2018, 14, 21-35. [CrossRef]

129. Keller, A.C.; Badani, H.; McClatchey, P.M.; Baird, N.L.; Bowlin, J.L.; Bouchard, R.; Perng, O.; Reusch, J.E.B.; Kaufer, B.B.; Gilden, D.; et al. Varicella zoster virus infection of human fetal lung cells alters mitochondrial morphology. J. Neuro Virol. 2016, 22, 674-682. [CrossRef]

130. Gogvadze, V.; Zhivotovsky, B.; Orrenius, S. The Warburg effect and mitochondrial stability in cancer cells. Mol. Asp. Med. 2010, 31, 60-74. [CrossRef]

131. Liu, X.; Li, Q.; Dowdell, K.; Fischer, E.R.; Cohen, J.I. Varicella-Zoster virus ORF12 protein triggers phosphorylation of ERK1/2 and inhibits apoptosis. J. Virol. 2012, 86, 3143-3151. [CrossRef]

132. Carvalho, F.; Spier, A.; Chaze, T.; Matondo, M.; Cossart, P.; Stavru, F. Listeria monocytogenes Exploits Mitochondrial Contact Site and Cristae Organizing System Complex Subunit Mic10 To Promote Mitochondrial Fragmentation and Cellular Infection. mBio 2020, 11. [CrossRef] [PubMed]

133. Stavru, F.; Bouillaud, F.; Sartori, A.; Ricquier, D.; Cossart, P. Listeria monocytogenes transiently alters mitochondrial dynamics during infection. Proc. Natl. Acad. Sci. USA 2011, 108, 3167-3612. [CrossRef] [PubMed]

134. Stavru, F.; Palmer, A.E.; Wang, C.; Youle, R.J.; Cossart, P. Atypical mitochondrial fission upon bacterial infection. Proc. Natl. Acad. Sci. USA 2013, 110, 16003-16008. [CrossRef] [PubMed]

135. Escoll, P.; Song, O.-R.; Viana, F.; Steiner, B.; Lagache, T.; Olivo-Marin, J.-C.; Impens, F.; Brodin, P.; Hilbi, H.; Buchrieser, C. Legionella pneumophila Modulates Mitochondrial Dynamics to Trigger Metabolic Repurposing of Infected Macrophages. Cell Host Microbe 2017, 22, 302-316. [CrossRef] [PubMed]

136. Chowdhury, S.R.; Reimer, A.; Sharan, M.; Kozjak-Pavlovic, V.; Eulalio, A.; Prusty, B.K.; Fraunholz, M.; Karunakaran, K.; Rudel, T. Chlamydia preserves the mitochondrial network necessary for replication via microRNA-dependent inhibition of fission. J. Cell Biol. 2017, 216, 1071-1089. [CrossRef] [PubMed]

137. Abdul-Sater, A.A.; Saïd-Sadier, N.; Lam, V.M.; Singh, B.; Pettengill, M.A.; Soares, F.; Tattoli, I.; Lipinski, S.; Girardin, S.E.; Rosenstiel, P.; et al. Enhancement of Reactive Oxygen Species Production and Chlamydial Infection by the Mitochondrial Nod-like Family Member NLRX1. J. Biol. Chem. 2010, 285, 41637-41645. [CrossRef]

138. Boncompain, G.; Schneider, B.; Delevoye, C.; Kellermann, O.; Dautry-Varsat, A.; Subtil, A. Production of Reactive Oxygen Species Is Turned on and Rapidly Shut Down in Epithelial Cells Infected with Chlamydia trachomatis. Infect. Immun. 2010, 78, 80-87. [CrossRef] 
139. Jain, P.; Luo, Z.Q.; Blanke, S.R. Helicobacter pylori vacuolating cytotoxin A (VacA) engages the mitochondrial fission machinery to induce host cell death. Proc. Natl. Acad. Sci. USA 2011, 108, 16032-16037. [CrossRef]

140. Lum, M.; Morona, R. Dynamin-related protein Drp1 and mitochondria are important for Shigella flexneri infection. Int. J. Med. Microbiol. 2014, 304, 530-541. [CrossRef]

141. Sirianni, A.; Krokowski, S.; Lobato-Márquez, D.; Buranyi, S.; Pfanzelter, J.; Galea, D.; Willis, A.; Culley, S.; Henriques, R.; Larrouy-Maumus, G.; et al. Mitochondria mediate septin cage as-sembly to promote autophagy of Shigella. EMBO Rep. 2016, 17, 1029-1043. [CrossRef] [PubMed]

142. Chen, M.; Gan, H.; Remold, H.G. A mechanism of virulence: Virulent Mycobacterium tuberculosis strain H37Rv, but not at-tenuated H37Ra, causes significant mitochondrial inner membrane disruption in macrophages leading to necrosis. J Immunol. 2006, 176, 3707-3716. [CrossRef] [PubMed]

143. Jamwal, S.; Midha, M.K.; Verma, H.N.; Basu, A.; Rao, K.V.; Manivel, V. Characterizing virulence-specific perturbations in the mito-chondrial function of macrophages infected with Mycobacterium tuberculosis. Sci. Rep. 2013, 3, 1328. [CrossRef] [PubMed]

144. Vyatkina, G.; Bhatia, V.; Gerstner, A.; Papaconstantinou, J.; Garg, N. Impaired mitochondrial respiratory chain and bioenergetics during chagasic cardiomyopathy development. Biochim. et Biophys. Acta (BBA) Mol. Basis Dis. 2004, 1689, 162-173. [CrossRef]

145. Wen, J.; Yachelini, P.C.; Sembaj, A.; Manzur, R.E.; Garg, N.J. Increased oxidative stress is correlated with mitochondrial dysfunction in chagasic patients. Free. Radic. Biol. Med. 2006, 41, 270-276. [CrossRef]

146. Gupta, S.; Wen, J.J.; Garg, N.J. Oxidative stress in Chagas disease. Interdiscip. Perspect. Infect. Dis. 2009, 2009, 190354. [CrossRef]

147. Wen, J.-J.; Garg, N. Oxidative modification of mitochondrial respiratory complexes in response to the stress of Trypanosoma cruzi infection. Free. Radic. Biol. Med. 2004, 37, 2072-2081. [CrossRef]

148. Rojas Marquez, J.D.; Ana, Y.; Baigorri, R.E.; Stempin, C.C.; Cerban, F.M. Mammalian Target of Rapamycin Inhibition in Trypanosoma cruzi-Infected Macrophages Leads to an Intracellular Profile That Is Detrimental for Infection. Front. Immunol. 2018, 9, 313. [CrossRef]

149. Wan, X.; Gupta, S.; Zago, M.P.; Davidson, M.M.; Dousset, P.; Amoroso, A.; Garg, N.J. Defects of mtDNA replication impaired mitochondrial biogenesis during Trypanosoma cruzi infection in human cardiomyocytes and chagasic patients: The role of Nrf1/2 and anti-oxidant response. J. Am. Heart. Assoc. 2012, 1, e003855. [CrossRef]

150. Wen, J.J.; Yin, Y.W.; Garg, N.J. PARP1 depletion improves mitochondrial and heart function in Chagas disease: Effects on POLG dependent mtDNA maintenance. PLoS Pathog. 2018, 14, e1007065. [CrossRef]

151. Gupta, S.; Bhatia, V.; Wen, J.-J.; Wu, Y.; Huang, M.-H.; Garg, N.J. Trypanosoma cruzi infection disturbs mitochondrial membrane potential and ROS production rate in cardiomyocytes. Free. Radic. Biol. Med. 2009, 47, 1414-1421. [CrossRef]

152. Wen, J.J.; Dhiman, M.; Whorton, E.B.; Garg, N.J. Tissue-specific oxidative imbalance and mitochondrial dysfunction during Trypa-nosoma cruzi infection in mice. Microbes Infect. 2008, 10, 1201-1209. [CrossRef]

153. Gonzalez-Ortiz, L.M.; Sanchez-Villamil, J.P.; Celis-Rodriguez, M.A.; Lineros, G.; Sanabria-Barrera, S.; Serrano, N.C.; Rincon, M.Y.; Bautista-Nino, P.K. Measuring mitochondrial respiration in adherent cells infected with Trypanosoma cruzi Chagas, 1909 using Seahorse extracellular flux analyser. Folia Parasitol. 2019, 66, 1-9. [CrossRef] [PubMed]

154. Shivappagowdar, A.; Garg, S.; Srivastava, A.; Hada, R.; Kalia, I.; Singh, A.; Garg, L.; Pati, S.; Singh, S. Pathogenic Pore Forming Proteins of Plasmodium Triggers the Necrosis of Endothelial Cells Attributed to Malaria Severity. Toxins 2021, 13, 62. [CrossRef]

155. Kaushansky, A.; Metzger, P.G.; Douglass, A.N.; Mikolajczak, S.A.; Lakshmanan, V.; Kain, H.S.; Kappe, S.H. Malaria parasite liver stages render host hepatocytes susceptible to mitochondria-initiated apoptosis. Cell Death Dis. 2013, 4, e762. [CrossRef]

156. Kaushansky, A.; Ye, A.S.; Austin, L.S.; Mikolajczak, S.; Vaughan, A.M.; Camargo, N.; Metzger, P.G.; Douglass, A.N.; MacBeath, G.; Kappe, S.H. Suppression of Host p53 Is Critical for Plasmodium Liver-Stage Infection. Cell Rep. 2013, 3, 630-637. [CrossRef]

157. Martinou, J.-C.; Youle, R.J. Mitochondria in Apoptosis: Bcl-2 Family Members and Mitochondrial Dynamics. Dev. Cell 2011, 21, 92-101. [CrossRef] [PubMed]

158. Syn, G.; Anderson, D.; Blackwell, J.M.; Jamieson, S.E. Toxoplasma gondii Infection Is Associated with Mitochondrial Dysfunction in-Vitro. Front. Cell. Infect. Microbiol. 2017, 7, 512. [CrossRef] [PubMed]

159. Pernas, L.; Bean, C.; Boothroyd, J.C.; Scorrano, L. Mitochondria Restrict Growth of the Intracellular Parasite Toxoplasma gondii by Limiting Its Uptake of Fatty Acids. Cell Metab. 2018, 27, 886-897.e4. [CrossRef] [PubMed]

160. Blader, I.J.; Manger, I.D.; Boothroyd, J.C. Microarray Analysis Reveals Previously Unknown Changes in Toxoplasma gondiiinfected Human Cells. J. Biol. Chem. 2001, 276, 24223-24231. [CrossRef] [PubMed]

161. He, J.-J.; Ma, J.; Li, F.-C.; Song, H.-Q.; Xu, M.-J.; Zhu, X.-Q. Transcriptional changes of mouse splenocyte organelle components following acute infection with Toxoplasma gondii. Exp. Parasitol. 2016, 167, 7-16. [CrossRef]

162. Chakrabarty, Y.; Bhattacharyya, S.N. Leishmania donovani restricts mitochondrial dynamics to enhance miRNP stability and target RNA repression in host macrophages. Mol. Biol. Cell. 2017, 28, 2091-2105. [CrossRef]

163. Moreira, D.; Rodrigues, V.; Abengozar, M.; Rivas, L.; Rial, E.; Laforge, M.; Li, X.; Foretz, M.; Viollet, B.; Estaquier, J.; et al Leishmania infantum Modulates Host Macrophage Mitochondrial Metabolism by Hijacking the SIRT1-AMPK Axis. PLoS Pathog. 2015, 11, e1004684. [CrossRef]

164. Eisenreich, W.; Rudel, T.; Heesemann, J.; Goebel, W. How Viral and Intracellular Bacterial Pathogens Reprogram the Metabolism of Host Cells to Allow Their Intracellular Replication. Front. Cell. Infect. Microbiol. 2019, 9, 42. [CrossRef] [PubMed]

165. Cruz-Gregorio, A.; Aranda-Rivera, A.K.; Pedraza-Chaverri, J. Human Papillomavirus-related Cancers and Mitochondria. Virus Res. 2020, 286, 198016. [CrossRef] [PubMed] 
166. Kim, Y.R.; Kim, J.S.; Yun, J.S.; Kim, S.; Kim, S.Y.; Jang, K.; Yang, C.S. Toxoplasma gondii GRA8 induces ATP5A1-SIRT3-mediated mito-chondrial metabolic resuscitation: A potential therapy for sepsis. Exp. Mol. Med. 2018, 50, e464. [CrossRef] [PubMed]

167. Dustin, M.L. The immunological synapse. Cancer Immunol. Res. 2014, 2, 1023-1033. [CrossRef] [PubMed]

168. Jiang, H.W.; Zhang, H.N.; Meng, Q.F.; Xie, J.; Li, Y.; Chen, H.; Zheng, Y.X.; Wang, X.N.; Qi, H.; Zhang, J.; et al. SARS-CoV-2 Orf9b suppresses type I interferon responses by targeting TOM70. Cell Mol. Immunol. 2020, 17, 998-1000. [CrossRef]

169. Kalashnyk, O.; Lykhmus, O.; Izmailov, M.; Koval, L.; Komisarenko, S.; Skok, M. SARS-Cov-2 spike protein fragment 674-685 protects mitochondria from releasing cytochrome $\mathrm{c}$ in response to apoptogenic influence. Biochem. Biophys. Res. Commun. 2021, 561, 14-18. [CrossRef]

170. Flannagan, R.S.; Cosío, G.; Grinstein, S. Antimicrobial mechanisms of phagocytes and bacterial evasion strategies. Nat. Rev. Genet. 2009, 7, 355-366. [CrossRef]

171. Spier, A.; Stavru, F.; Cossart, P. Interaction between Intracellular Bacterial Pathogens and Host Cell Mitochondria. Microbiol. Spectr. 2019, 7, 2. [CrossRef] [PubMed]

172. Mohareer, K.; Medikonda, J.; Vadankula, G.R.; Banerjee, S. Mycobacterial Control of Host Mitochondria: Bioenergetic and Metabolic Changes Shaping Cell Fate and Infection Outcome. Front. Cell. Infect. Microbiol. 2020, 10, 457. [CrossRef]

173. Lee, K.; Choi, S.; Choi, H.; Gurmessa, S.K.; Dang, T.B.; Back, Y.W.; Park, H.; Kim, H. Recombinant Rv1654 protein of Mycobacterium tuberculosis induces mitochondria-mediated apoptosis in macrophage. Microbiol. Immunol. 2021, 65, 178-188. [CrossRef]

174. Voleman, L.; Dolezal, P. Mitochondrial dynamics in parasitic protists. PLoS Pathog. 2019, 15, e1008008. [CrossRef]

175. Cunha-Neto, E.; Chevillard, C. Chagas disease cardiomyopathy: Immunopathology and genetics. Mediators Inflamm. 2014, 2014, 683230. [CrossRef] [PubMed]

176. Da Silveira, A.B.M.; Lemos, E.M.; Adad, S.J.; Correa-Oliveira, R.; Furness, J.B.; Reis, D.D.A. Megacolon in Chagas disease: A study of inflammatory cells, enteric nerves, and glial cells. Hum. Pathol. 2007, 38, 1256-1264. [CrossRef] [PubMed]

177. Paiva, C.N.; Medei, E.; Bozza, M.T. ROS and Trypanosoma cruzi: Fuel to infection, poison to the heart. PLoS Pathog. 2018, 14, e1006928. [CrossRef]

178. Milduberger, N.; Bustos, P.L.; González, C.; Perrone, A.E.; Postan, M.; Bua, J. Trypanosoma cruzi infection in Cyclophilin D deficient mice. Exp. Parasitol. 2020, 220, 108044. [CrossRef] [PubMed]

179. Hossain, E.; Khanam, S.; Dean, D.A.; Wu, C.; Lostracco-Johnson, S.; Thomas, D.; Kane, S.S.; Parab, A.R.; Flores, K.; Katemauswa, M.; et al. Mapping of host-parasite-microbiome inter-actions reveals metabolic determinants of tropism and tolerance in Chagas disease. Sci. Adv. 2020, 6, eaaz2015. [CrossRef] [PubMed]

180. Liu, Z.; Ulrich vonBargen, R.; McCall, L.I. Central role of metabolism in Trypanosoma cruzi tropism and Chagas disease patho-genesis. Curr. Opin. Microbiol. 2021, 63, 204-229. [CrossRef]

181. Subauste, C.S. Recent Advances in the Roles of Autophagy and Autophagy Proteins in Host Cells During Toxoplasma gondii Infection and Potential Therapeutic Implications. Front. Cell Dev. Biol. 2021, 9. [CrossRef]

182. Pernas, L.; Adomako-Ankomah, Y.; Shastri, A.J.; Ewald, S.E.; Treeck, M.; Boyle, J.P.; Boothroyd, J.C. Toxoplasma effector MAF1 mediates re-cruitment of host mitochondria and impacts the host response. PLoS Biol. 2014, 12, e1001845. [CrossRef]

183. Nelson, M.M.; Jones, A.R.; Carmen, J.C.; Sinai, A.P.; Burchmore, R.; Wastling, J.M. Modulation of the host cell proteome by the intra-cellular apicomplexan parasite Toxoplasma gondii. Infect. Immun. 2008, 76, 828-844. [CrossRef]

184. Blank, M.L.; Xia, J.; Morcos, M.M.; Sun, M.; Cantrell, P.S.; Liu, Y.; Zeng, X.; Powell, C.J.; Yates, N.; Boulanger, M.J.; et al. Toxoplasma gondii association with host mitochondria requires key mitochondrial protein import machinery. Proc. Natl. Acad. Sci. USA 2021, 118, e2013336118. [CrossRef]

185. Su, X.-Z.; Zhang, C.; Joy, D.A. Host-Malaria Parasite Interactions and Impacts on Mutual Evolution. Front. Cell. Infect. Microbiol. 2020, 10, 587933. [CrossRef]

186. Scarpelli, P.H.; Pecenin, M.F.; Garcia, C.R.S. Intracellular $\mathrm{Ca}^{2+}$ Signaling in Protozoan Parasites: An Overview with a Focus on Mitochondria. Int. J. Mol. Sci. 2021, 22, 469. [CrossRef]

187. Ryan, M.T.; Hoogenraad, N.J. Mitochondrial-Nuclear Communications. Annu. Rev. Biochem. 2007, 76, 701-722. [CrossRef] [PubMed]

188. Soledad, R.B.; Charles, S.; Samarjit, D. The secret messages between mitochondria and nucleus in muscle cell biology. Arch. Biochem. Biophys. 2019, 666, 52-62. [CrossRef] [PubMed]

189. Rius-Pérez, S.; Torres-Cuevas, I.; Millán, I.; Ortega, Á.L.; Pérez, S. PGC-1alpha, Inflammation, and Oxidative Stress: An Integrative View in Metabolism. Oxid. Med. Cell Longev. 2020, 2020, 1452696. [CrossRef] [PubMed]

190. Xiong, S.; Patrushev, N.; Forouzandeh, F.; Hilenski, L.; Alexander, R.W. PGC-1 $\alpha$ Modulates Telomere Function and DNA Damage in Protecting against Aging-Related Chronic Diseases. Cell Rep. 2015, 12, 1391-1399. [CrossRef]

191. Leone, T.C.; Lehman, J.J.; Finck, B.N.; Schaeffer, P.J.; Wende, A.R.; Boudina, S.; Courtois, M.; Wozniak, D.F.; Sambandam, N.; Bernal-Mizrachi, C.; et al. PGC-1alpha deficiency causes multi-system energy metabolic derangements: Muscle dysfunction, abnormal weight control and hepatic steatosis. PLoS Biol. 2005, 3, e101. [CrossRef]

192. Fontecha-Barriuso, M.; Martín-Sánchez, D.; Martinez-Moreno, J.M.; Carrasco, S.; Ruiz-Andrés, O.; Monsalve, M.; Sanchez-Ramos, C.; Gómez, M.J.; Ruiz-Ortega, M.; Sánchez-Niño, M.D.; et al. PGC-1alpha deficiency causes spontaneous kidney inflammation and increases the severity of nephrotoxic AKI. J. Pathol. 2019, 249, 65-78. [CrossRef] [PubMed] 
193. Chambers, K.T.; Chen, Z.; Crawford, P.; Fu, X.; Burgess, S.C.; Lai, L.; Leone, T.C.; Kelly, D.P.; Finck, B.N. Liver-Specific PGC-1beta Deficiency Leads to Impaired Mitochondrial Function and Lipogenic Response to Fasting-Refeeding. PLoS ONE 2012, 7, e52645. [CrossRef]

194. Bloise, F.F.; Santos, A.T.; de Brito, J.; de Andrade, C.B.V.; Oliveira, T.S.; de Souza, A.F.P.; Fontes, K.N.; Silva, J.D.; Blanco, N.; Silva, P.L.; et al. Sepsis Impairs Thyroid Hormone Signaling and Mitochondrial Function in the Mouse Diaphragm. Thyroid 2020, 30, 1079-1090. [CrossRef]

195. Suliman, H.B.; Welty-Wolf, K.E.; Carraway, M.; Tatro, L.; Piantadosi, C.A. Piantadosi CA. Lipopolysaccharide induces oxidative cardiac mitochon-drial damage and biogenesis. Cardiovasc. Res. 2004, 64, 279-288. [CrossRef]

196. Tzika, A.A.; Constantinou, C.; Bandyopadhaya, A.; Psychogios, N.; Lee, S.; Mindrinos, M.; Martyn, J.A.J.; Tompkins, R.G.; Rahme, L.G. A Small Volatile Bacterial Molecule Triggers Mitochondrial Dysfunction in Murine Skeletal Muscle. PLoS ONE 2013, 8, e74528. [CrossRef]

197. Herzig, S.; Shaw, R.J. AMPK: Guardian of metabolism and mitochondrial homeostasis. Nat. Rev. Mol. Cell Biol. 2018, 19, 121-135. [CrossRef]

198. Yang, C.-S.; Kim, J.-J.; Lee, H.-M.; Jin, H.S.; Lee, S.-H.; Park, J.-H.; Kim, S.J.; Kim, J.-M.; Han, Y.-M.; Lee, M.-S.; et al. The AMPK-PPARGC1A pathway is required for antimicrobial host defense through activation of autophagy. Autophagy 2014, 10, 785-802. [CrossRef] [PubMed]

199. Gureev, A.P.; Shaforostova, E.A.; Popov, V. Regulation of Mitochondrial Biogenesis as a Way for Active Longevity: Interaction Between the Nrf2 and PGC-1 $\alpha$ Signaling Pathways. Front. Genet. 2019, 10, 435. [CrossRef]

200. Piantadosi, C.A.; Suliman, H.B. Mitochondrial Transcription Factor A Induction by Redox Activation of Nuclear Respiratory Factor 1. J. Biol. Chem. 2006, 281, 324-333. [CrossRef] [PubMed]

201. Scarpulla, R.C.; Vega, R.B.; Kelly, D.P. Transcriptional integration of mitochondrial biogenesis. Trends Endocrinol. Metab. 2012, 23 , 459-466. [CrossRef] [PubMed]

202. Olagnier, D.; Peri, S.; Steel, C.; Van Montfoort, N.; Chiang, C.; Beljanski, V.; Slifker, M.; He, Z.; Nichols, C.N.; Lin, R.; et al. Cellular Oxidative Stress Response Controls the Antiviral and Apoptotic Programs in Dengue Virus-Infected Dendritic Cells. PLoS Pathog. 2014, 10, e1004566. [CrossRef] [PubMed]

203. Ferrari, M.; Zevini, A.; Palermo, E.; Muscolini, M.; Alexandridi, M.; Etna, M.P.; Coccia, E.M.; Fernandez-Sesma, A.; Coyne, C.; Zhang, D.D.; et al. Dengue Virus Targets Nrf2 for NS2B3-Mediated Degradation Leading to Enhanced Oxidative Stress and Viral Replication. J. Virol. 2020, 94. [CrossRef] [PubMed]

204. Fan, X.; Murray, S.C.; Staitieh, B.S.; Spearman, P.; Guidot, D.M. HIV Impairs Alveolar Macrophage Function via Mi-croRNA-144Induced Suppression of Nrf2. Am. J. Med. Sci. 2021, 361, 90-97. [CrossRef] [PubMed]

205. Staitieh, B.S.; Ding, L.; Neveu, W.A.; Spearman, P.; Guidot, D.M.; Fan, X. HIV-1 decreases Nrf2/ARE activity and phagocytic function in alveolar macrophages. J. Leukoc. Biol. 2017, 102, 517-525. [CrossRef]

206. Wyler, E.; Franke, V.; Menegatti, J.; Kocks, C.; Boltengagen, A.; Praktiknjo, S.; Walch-Rückheim, B.; Bosse, J.; Rajewsky, N.; Grässer, F.; et al. Single-cell RNA-sequencing of herpes simplex virus 1-infected cells connects NRF2 activation to an antiviral program. Nat. Commun. 2019, 10, 1-14. [CrossRef]

207. Yun, S.-M.; Kim, Y.S.; Hur, D.Y. LMP1 and 2A Induce the Expression of Nrf2 Through Akt Signaling Pathway in Epstein-Barr Virus-Transformed B Cells. Transl. Oncol. 2019, 12, 775-783. [CrossRef]

208. Feng, J.; Chen, Q.; Zhang, P.; Huang, X.; Xie, W.; Zhang, H.; Yao, P. Latent Membrane Protein 1 Promotes Tumorigenesis Through Upregulation of PGC1beta Signaling Pathway. Stem Cell Rev. Rep. 2021, 17, 1486-1499. [CrossRef]

209. Wang, W.; Zhang, Y.; Liu, W.; Zhang, X.; Xiao, H.; Zhao, M.; Luo, B. CXCR4 induces cell autophagy and maintains EBV latent infection in EBVaGC. Theranostics 2020, 10, 11549-11561. [CrossRef]

210. Olagnier, D.; Farahani, E.; Thyrsted, J.; Blay-Cadanet, J.; Herengt, A.; Idorn, M.; Hait, A.; Hernaez, B.; Knudsen, A.; Iversen, M.B.; et al. SARS-CoV2-mediated suppression of NRF2-signaling reveals potent antiviral and anti-inflammatory activity of 4-octyl-itaconate and dimethyl fumarate. Nat. Commun. 2020, 11, 4938. [CrossRef]

211. Takiuchi, Y.; Kobayashi, M.; Tada, K.; Iwai, F.; Sakurada, M.; Hirabayashi, S.; Nagata, K.; Shirakawa, K.; Shindo, K.; Yasunaga, J.-I.; et al. HTLV-1 bZIP factor suppresses TDP1 expression through inhibition of NRF-1 in adult T-cell leukemia. Sci. Rep. 2017, 7, 12849. [CrossRef] [PubMed]

212. Suliman, H.B.; Kraft, B.; Bartz, R.; Chen, L.; Welty-Wolf, K.E.; Piantadosi, C.A. Mitochondrial quality control in alveolar epithelial cells damaged by S. aureus pneumonia in mice. Am. J. Physiol. Cell. Mol. Physiol. 2017, 313, L699-L709. [CrossRef] [PubMed]

213. Bartz, R.R.; Suliman, H.B.; Fu, P.; Welty-Wolf, K.; Carraway, M.S.; MacGarvey, N.C.; Withers, C.M.; Sweeney, T.E.; Piantadosi, C.A. Staphylococcus aureus sepsis and mito-chondrial accrual of the 8-oxoguanine DNA glycosylase DNA repair enzyme in mice. Am. J. Respir. Crit. Care Med. 2011, 183, 226-233. [CrossRef]

214. Bartz, R.R.; Fu, P.; Suliman, H.B.; Crowley, S.D.; MacGarvey, N.C.; Welty-Wolf, K.; Piantadosi, C.A. Staphylococcus aureus Sepsis Induces Early Renal Mitochondrial DNA Repair and Mitochondrial Biogenesis in Mice. PLoS ONE 2014, 9, e100912. [CrossRef]

215. Suliman, H.B.; Babiker, A.; Withers, C.M.; Sweeney, T.E.; Carraway, M.S.; Tatro, L.G.; Bartz, R.R.; Welty-Wolf, K.E.; Piantadosi, C.A. Nitric oxide synthase-2 regulates mito-chondrial Hsp60 chaperone function during bacterial peritonitis in mice. Free Radic. Biol. Med. 2010, 48, 736-746. [CrossRef]

216. Ramos, S.; Carlos, A.R.; Sundaram, B.; Jeney, V.; Ribeiro, A.; Gozzelino, R.; Bank, C.; Gjini, E.; Braza, F.; Martins, R.; et al. Renal control of disease tolerance to malaria. Proc. Natl. Acad. Sci. USA 2019, 116, 5681-5686. [CrossRef] 
217. Reverte, M.; Eren, R.O.; Jha, B.; Desponds, C.; Snäkä, T.; Prevel, F.; Isorce, N.; Lye, L.-F.; Owens, K.L.; Lopes, U.G.; et al. The antioxidant response favors Leishmania parasites survival, limits inflammation and reprograms the host cell metabolism. PLoS Pathog. 2021, 17, e1009422. [CrossRef] [PubMed]

218. Xu, L.; Sang, R.; Yu, Y.; Li, J.; Ge, B.; Zhang, X. The polysaccharide from Inonotus obliquus protects mice from Toxoplasma gondii-induced liver injury. Int. J. Biol. Macromol. 2018, 125, 1-8. [CrossRef]

219. Aldaba-Muruato, L.R.; Muñoz-Ortega, M.H.; Macías-Pérez, J.R.; Pulido-Ortega, J.; Martínez-Hernández, S.L.; Ventura-Juárez, J. Ad-renergic regulation during acute hepatic infection with Entamoeba histolytica in the hamster: Involvement of oxidative stress, Nrf2 and NF-KappaB. Parasite 2017, 24, 46. [CrossRef]

220. Ni, H.; Wang, Y.; An, K.; Liu, Q.; Xu, L.; Zhu, C.; Deng, H.; He, Q.; Wang, T.; Xu, M.; et al. Crosstalk between NFkappaB-dependent astrocytic CXCL1 and neuron CXCR2 plays a role in descending pain facilitation. J. Neuroinflamm. 2019, 16, 1-16. [CrossRef]

221. Paiva, C.N.; Feijó, D.F.; Dutra, F.F.; Carneiro, V.; De Freitas, G.; Alves, L.S.; Mesquita, J.; Fortes, G.B.; Figueiredo, R.; de Souza, H.; et al. Oxidative stress fuels Trypanosoma cruzi infection in mice. J. Clin. Investig. 2012, 122, 2531-2542. [CrossRef]

222. Sivanand, S.; Viney, I.; Wellen, K.E. Spatiotemporal Control of Acetyl-CoA Metabolism in Chromatin Regulation. Trends Biochem. Sci. 2018, 43, 61-74. [CrossRef]

223. Lozoya, O.A.; Wang, T.; Grenet, D.; Wolfgang, T.C.; Sobhany, M.; Da Silva, D.G.; Riadi, G.; Chandel, N.; Woychik, R.P.; Santos, J.H. Mitochondrial acetyl-CoA reversibly regulates locus-specific histone acetylation and gene expression. Life Sci. Alliance 2019, 2. [CrossRef]

224. Pei, Y.; Robertson. E.S. The Crosstalk of Epigenetics and Metabolism in Herpesvirus Infection. Viruses 2020, 12, 1377. [CrossRef]

225. Kincaid, E.Z.; Ernst, J.D. Mycobacterium tuberculosis exerts gene-selective inhibition of transcriptional responses to IFN-gamma without inhibiting STAT1 function. J. Immunol. 2003, 171, 2042-2049. [CrossRef] [PubMed]

226. Eskandarian, H.A.; Impens, F.; Nahori, M.-A.; Soubigou, G.; Coppée, J.-Y.; Cossart, P.; Hamon, M.A. A Role for SIRT2-Dependent Histone H3K18 Deacetylation in Bacterial Infection. Science 2013, 341, 1238858. [CrossRef]

227. Ariffin, J.K.; das Gupta, K.; Kapetanovic, R.; Iyer, A.; Reid, R.C.; Fairlie, D.P.; Sweet, M.J. Histone Deacetylase Inhibitors Promote Mitochon-drial Reactive Oxygen Species Production and Bacterial Clearance by Human Macrophages. Antimicrob. Agents Chemother. 2015, 60, 1521-1529. [CrossRef] [PubMed]

228. Matilainen, O.; Quiros, P.M.; Auwerx, J. Mitochondria and Epigenetics-Crosstalk in Homeostasis and Stress. Trends Cell Biol. 2017, 27, 453-463. [CrossRef]

229. Connor, M.G.; Camarasa, T.M.N.; Patey, E.; Rasid, O.; Barrio, L.; Weight, C.M.; Miller, D.P.; Heyderman, R.S.; Lamont, R.J.; Enninga, J.; et al. The histone demethylase KDM6B fine-tunes the host response to Streptococcus pneumoniae. Nat. Microbiol. 2020, 6, 257-269. [CrossRef] [PubMed]

230. Singh, R.; Chandrashekharappa, S.; Bodduluri, H.; Baby, B.V.; Hegde, B.; Kotla, N.G.; Hiwale, A.A.; Saiyed, T.; Patel, P.; VijayKumar, M.; et al. Enhancement of the gut barrier integrity by a microbial metabolite through the Nrf2 pathway. Nat. Commun. 2019, 10, 1-18. [CrossRef]

231. Tuohetaerbaike, B.; Zhang, Y.; Tian, Y.; Zhang, N.N.; Kang, J.; Mao, X.; Zhang, Y.; Li, X. Pancreas protective effects of Urolithin A on type 2 diabetic mice induced by high fat and streptozotocin via regulating autophagy and AKT/mTOR signaling pathway. $J$. Ethnopharmacol. 2019, 250, 112479. [CrossRef]

232. Taube, D.; Xu, J.; Yang, X.P.; Undrovinas, A.; Peterson, E.; Harding, P. Fractalkine depresses cardiomyocyte contractility. PLoS ONE 2013, 8, e69832. [CrossRef]

233. Fang, E.F.; Hou, Y.; Palikaras, K.; Adriaanse, B.A.; Kerr, J.S.; Yang, B.; Lautrup, S.; Hasan-Olive, M.M.; Caponio, D.; Dan, X.; et al. Mitophagy inhibits amyloid-beta and tau pathology and reverses cognitive deficits in models of Alzheimer's disease. Nat. Neurosci. 2019, 22, 401-412. [CrossRef] [PubMed]

234. Hertz, N.; Berthet, A.; Sos, M.L.; Thorn, K.; Burlingame, A.L.; Nakamura, K.; Shokat, K.M. A Neo-Substrate that Amplifies Catalytic Activity of Parkinson's-Disease-Related Kinase PINK1. Cell 2013, 154, 737-747. [CrossRef]

235. Hu, M.; Bogoyevitch, M.A.; Jans, D.A. Subversion of Host Cell Mitochondria by RSV to Favor Virus Production is Dependent on Inhibition of Mitochondrial Complex I and ROS Generation. Cells 2019, 8, 1417. [CrossRef]

236. Gane, E.J.; Weilert, F.; Orr, D.W.; Keogh, G.F.; Gibson, M.; Lockhart, M.M.; Frampton, C.M.; Taylor, K.M.; Smith, R.A.J.; Murphy, M. The mitochondria-targeted anti-oxidant mitoquinone decreases liver damage in a phase II study of hepatitis $C$ patients. Liver Int. 2010, 30, 1019-1026. [CrossRef]

237. Dashdorj, A.; Jyothi, K.; Lim, S.; Jo, A.; Nguyen, M.N.; Ha, J.; Yoon, K.S.; Kim, H.J.; Park, J.H.; Murphy, M.P.; et al. Mitochondriatargeted antioxidant MitoQ ameliorates experi-mental mouse colitis by suppressing NLRP3 inflammasome-mediated inflammatory cytokines. BMC Med. 2013, 11, 178. [CrossRef]

238. Onyango, I.; Jauregui, G.; Čarná, M.; Bennett, J.; Stokin, G. Neuroinflammation in Alzheimer's Disease. Biomedicines 2021, 9 , 524. [CrossRef]

239. Subbarao, S.; Sanchez-Garrido, J.; Krishnan, N.; Shenoy, A.R.; Robertson, B.D. Genetic and pharmacological inhibition of inflam-masomes reduces the survival of Mycobacterium tuberculosis strains in macrophages. Sci. Rep. 2020, 10, 3709. [CrossRef]

240. Zhou, Z.X.; Mou, S.F.; Chen, X.Q.; Gong, L.L.; Ge, W.S. Anti-inflammatory activity of resveratrol prevents inflammation by inhibiting NFkappaB in animal models of acute pharyngitis. Mol. Med. Rep. 2018, 17, 1269-1274. [PubMed] 
241. Patel, K.R.; Brown, V.A.; Jones, D.; Britton, R.G.; Hemingway, D.; Miller, A.S.; West, K.P.; Booth, T.D.; Perloff, M.; Crowell, J.A.; et al. Clinical Pharmacology of Resveratrol and Its Metabolites in Colorectal Cancer Patients. Cancer Res. 2010, 70, 7392-7399. [CrossRef]

242. Ding, M.; Feng, N.; Tang, D.; Feng, J.; Li, Z.; Jia, M.; Liu, Z.; Gu, X.; Wang, Y.; Fu, F.; et al. Melatonin prevents Drp1-mediated mitochondrial fission in diabetic hearts through SIRT1-PGC1 $\alpha$ pathway. J. Pineal Res. 2018, 65, e12491. [CrossRef] [PubMed]

243. Haileselassie, B.; Mukherjee, R.; Joshi, A.U.; Napier, B.A.; Massis, L.M.; Ostberg, N.; Queliconi, B.B.; Monack, D.; Bernstein, D.; Mochly-Rosen, D. Drp1/Fis1 interaction mediates mitochondrial dysfunction in septic cardiomyopathy. J. Mol. Cell. Cardiol. 2019, 130, 160-169. [CrossRef]

244. Qi, X.; Qvit, N.; Su, Y.-C.; Mochly-Rosen, D. Novel Drp1 inhibitor diminishes aberrant mitochondrial fission and neurotoxicity. J. Cell Sci. 2012, 126, 789-802. [CrossRef]

245. Caicedo, A.; Fritz, V.; Brondello, J.-M.; Ayala, M.; Dennemont, I.; Abdellaoui, N.; de Fraipont, F.; Moisan, A.; Prouteau, C.A.; Boukhaddaoui, H.; et al. MitoCeption as a new tool to assess the effects of mesenchymal stem/stromal cell mitochondria on cancer cell metabolism and function. Sci. Rep. 2015, 5, srep09073. [CrossRef]

246. Court, A.C.; Le-Gatt, A.; Luz-Crawford, P.; Parra, E.; Aliaga-Tobar, V.; Batiz, L.F.; Contreras, R.; Ortúzar, M.I.; Kurte, M.; Elizondo-Vega, R.; et al. Mitochondrial transfer from MSCs to T cells induces Treg differentiation and restricts inflammatory response. EMBO Rep. 2020, 21, e48052. [CrossRef] [PubMed]

247. Masuzawa, A.; Black, K.M.; Pacak, C.A.; Ericsson, M.; Barnett, R.J.; Drumm, C.; Seth, P.; Bloch, D.B.; Levitsky, S.; Cowan, D.B.; et al. Transplantation of autologously derived mito-chondria protects the heart from ischemia-reperfusion injury. Am. J. Physiol. Heart. Circ. Physiol. 2013, 304, H966-H982. [CrossRef]

248. Lin, H.-C.; Liu, S.-Y.; Lai, H.-S.; Lai, I.-R. Isolated Mitochondria Infusion Mitigates Ischemia-Reperfusion Injury of the Liver in Rats. Shock 2013, 39, 304-310. [CrossRef] [PubMed]

249. Huang, P.-J.; Kuo, C.-C.; Lee, H.-C.; Shen, C.-I.; Cheng, F.-C.; Wu, S.-F.; Chang, J.C.; Pan, H.-C.; Lin, S.-Z.; Liu, C.-S.; et al. Transferring Xenogenic Mitochondria Provides Neural Protection against Ischemic Stress in Ischemic Rat Brains. Cell Transplant. 2016, 25, 913-927. [CrossRef]

250. Spees, J.L.; Olson, S.; Whitney, M.J.; Prockop, D.J. Mitochondrial transfer between cells can rescue aerobic respiration. Proc. Natl. Acad. Sci. USA 2006, 103, 1283-1288. [CrossRef]

251. Rawat, P.; Teodorof-Diedrich, C.; Spector, S.A. Human immunodeficiency virus Type-1 single-stranded RNA activates the NLRP3 inflammasome and impairs autophagic clearance of damaged mitochondria in human microglia. Glia 2018, 67, 802-824. [CrossRef] [PubMed]

252. Ojeda, D.S.; Grasso, D.; Urquiza, J.; Till, A.; Vaccaro, M.I.; Quarleri, J. Cell Death Is Counteracted by Mitophagy in HIVProductively Infected Astrocytes but Is Promoted by Inflammasome Activation Among Non-productively Infected Cells. Front. Immunol. 2018, 9, 2633. [CrossRef] [PubMed]

253. D'Amico, D.; Andreux, P.A.; Valdés, P.; Singh, A.; Rinsch, C.; Auwerx, J. Impact of the Natural Compound Urolithin A on Health, Disease, and Aging. Trends Mol. Med. 2021, 27, 687-699. [CrossRef]

254. Talvani, A.; Teixeira, M.M. Inflammation and Chagas disease some mechanisms and relevance. Adv. Parasitol. 2011, 76, 171-194. [PubMed]

255. Naggie, S. Hepatitis C Virus, Inflammation, and Cellular Aging: Turning Back Time. Top. Antivir. Med. 2017, 25, 3-6.

256. Cecconi, M.; Evans, L.; Levy, M.; Rhodes, A. Sepsis and septic shock. Lancet 2018, 392, 75-87. [CrossRef]

257. Missiroli, S.; Perrone, M.; Boncompagni, C.; Borghi, C.; Campagnaro, A.; Marchetti, F.; Anania, G.; Greco, P.; Fiorica, F.; Pinton, P.; et al. Targeting the NLRP3 Inflammasome as a New Therapeutic Option for Overcoming Cancer. Cancers 2021, $13,2297$. [CrossRef]

258. Jiang, M.; Li, R.; Lyu, J.; Li, X.; Wang, W.; Wang, Z.; Sheng, H.; Zhang, W.; Karhausen, J.; Yang, W. MCC950, a selective NLPR3 inflammasome inhibitor, improves neurologic function and survival after cardiac arrest and resuscitation. J. Neuroinflamm. 2020, 17, 1-12. [CrossRef]

259. Coll, R.C.; Hill, J.R.; Day, C.J.; Zamoshnikova, A.; Boucher, D.; Massey, N.L.; Chitty, J.L.; Fraser, J.A.; Jennings, M.P.; Robertson, A.A.; et al. MCC950 directly targets the NLRP3 ATP-hydrolysis motif for inflammasome inhibition. Nat. Chem. Biol. 2019, 15, 556-559. [CrossRef]

260. Coll, R.; Robertson, A.; Chae, J.J.; Higgins, S.C.; Muñoz-Planillo, R.; Inserra, M.C.; Vetter, I.; Dungan, L.S.; Monks, B.G.; Stutz, A.; et al. A small-molecule inhibitor of the NLRP3 inflammasome for the treatment of inflammatory diseases. Nat. Med. 2015, 21, 248-255. [CrossRef]

261. Dempsey, C.; Araiz, A.R.; Bryson, K.J.; Finucane, O.; Larkin, C.; Mills, E.L.; Robertson, A.A.B.; Cooper, M.A.; O’Neill, L.A.J.; Lynch, M.A. Inhibiting the NLRP3 inflammasome with MCC950 promotes non-phlogistic clearance of amyloid-beta and cognitive function in APP/PS1 mice. Brain Behav. Immun. 2017, 61, 306-616. [CrossRef] [PubMed]

262. Freeman, T.; Swartz, T.H. Targeting the NLRP3 Inflammasome in Severe COVID-19. Front. Immunol. 2020, 11, 1518. [CrossRef] [PubMed]

263. McCully, J.D.; Cowan, D.B.; Pacak, C.A.; Toumpoulis, I.K.; Dayalan, H.; Levitsky, S. Injection of isolated mitochondria during early reperfusion for cardioprotection. Am. J. Physiol. Circ. Physiol. 2009, 296, H94-H105. [CrossRef] [PubMed] 